\title{
ALGORITMA UNTUK DETEKSI TUMPAHAN MINYAK DI LAUT TIMOR MENGGUNAKAN CITRA MODIS
}

\section{(ALGORITHMS TO DETECTED SPILL FROM USING MODIS IMAGE)}

\author{
Muhammad Sudibjo',2, Vincentius P. Siregar ${ }^{2}$, Jonson Lumban Gaol² \\ ${ }^{1}$ Corresponding author \\ ${ }^{2}$ Departemen Ilmu dan Teknologi Kelautan \\ Fakultas Perikanan dan Ilmu Kelautan, Institut Pertanan Bogor \\ E-mail: byo.sudibyo@gmail.com
}

\begin{abstract}
The Oil spill in Timor Sea in 2009 has spread the oil to the area of $10.842 .81 \mathrm{~km}^{2}$. It was successfully detected by MODIS. The main purposes of this research were to compare the detection result of spill from several algorithms with image by using MODIS image and see the visual difference generated. There were four algorithm used in this research, namely: Oil Spill Index, Fluorescence Index, Principal Component Analysis (PCA), and Normalized Difference Vegetation Index (NDVI). These five algorithms resulted in the following comparisons: the appearance of visualization of oil spill seen on MODIS image with oil spill index and fluorescence index algorithm was brighter than the surrounding water bodies and they had bigher pixel value. Mean while, oil visualization using PCA and NDVI algorithm was darker than the surrounding of water bodies and they had lower pixel value. The result of the test accuracy of oil spill index, fluorescence index, PCA, NDVI algorithm were $41 \%, 46 \%, 41 \%$, and $60 \%$ respectivety.
\end{abstract}

Keywords: Oil Spill, MODIS imagery, algorithm

\section{ABSTRAK}

Tumpahan minyak di Laut Timor yang terjadi pada tahun 2009 telah menyebarkan minyak seluas 10.842.81 km².Tumpahan minyak ini berhasil dideteksi oleh satelit Moderate Resolution Imaging Spectroradiometer (MODIS). Tujuan dari penelitian ini adalah membandingkan hasil deteksi tumpahan minyak dari beberapa algoritma dengan citra menggunakan citra MODIS dan melihat perbedaan visual yang dihasilkan. Algoritma yang digunakan adalah Oil Spill Index, Fluorescence Index, Principal Component Analysis (PCA), Normalized Difference Vegetation Index (NDVI). Visualisasi tumpahan minyak yang terlihat pada citra MODIS dengan algoritma oil spill indeks dan fluorescence index lebih cerah dibandingkan dengan badan air disekitarnya dan juga memiliki nilai piksel lebih tinggi, sedangkan visualisasi minyak menggunakan algoritma PCA dan NDVI lebih gelap dibandingkan dengan badan air disekitarnya dan juga memiliki nilai piksel yang lebih rendah. Hasil uji akurasi yang dilakukan terhadap algoritma oil splill index, fluorescence index, PCA, NDVI berturut-turut sebagai berikut $41 \%, 46 \%, 41 \%$, dan $60 \%$.

Kata kunci:Tumpahan minyak, citra MODIS, Algoritma

\section{PENDAHULUAN}

Salah satu aktivitas manusia yang dapat mencemari ekosistem laut adalah aktivitas pengeboran minyak bumi lepas pantai. Aktivitas ini jika tidak dilakukan dengan pengawasan dan perancanaan yang baik akan berakibat fatal yaitu dapat menyebabkan tumpahnya minyak ke permukaan laut (oil spill). Walaupun minyak memiliki peranan yang penting bagi perekonomian suatu negara, namun minyak dapat mencemarkan dan merusak ekosistem jika tidak dikelola dengan baik. Tumpahan minyak di laut akan menyebabkan kerugian, baik dilihat dari aspek ekonomi maupun ekologi. Keru- gian dari aspek ekonomi misalnya menyebabkan menurunnya hasil tangkapan perikanan (ikan dan kerang-kerangan), produksi rumput laut, produksi benih, kunjungan wisata yang berakibat menurunnya pendapatan nelayan. Dampak dari aspek ekologi yaitu: 1) Kerusakan hutan bakau, 2) kerusakan terumbu karang, lamun, 3) Kerusakan habitat pemijahan (spawning ground) dan pembesaran (nursery ground), 4) Kerusakan pantai, 5) Kerusakan dasar perairan pantai (siltasi lumpur, pasir, batuan) (Lumban Batu, 2010).

Berdasarkan tinjauan ekologisnya, lapisan minyak dipermukaan air laut dapat menghambat penetrasi cahaya 
matahari masuk ke dalam kolom perairan sehingga laju fotosintesis akan tergangu dan berkurang yang meyebabkan penurunan produktivitas primer perairan. Ketika produktivitas primer berkurang dalam rantai makanan dilaut, maka makanan untuk konsumen tingkat satu akan berkurang sehingga persaingan merebutkan makanan oleh organisme tingkat diatasnya meningkat dan menyebabkan banyak kematian, yang akan terus belanjut hingga konsumen tingkat atas (Lumban Batu, 2010).

Ketika minyak masuk ke lingkungan laut, maka minyak tersebut dengan segera akan mengalami proses perubahan secara fisik dan kimia. Menurut Mukhtosar (2007) diantara proses tersebut adalah terbentuknya lapisan (oil slick), tersebar (dissolution), penguapan (evaporation), polimerasi (polymerization), emulsifikasi (emulsification), emulsi minyak dalam air (oil in water emulsions), fotooksida, biodegradasi mikroba, sedimentasi, dicerna oleh plankton, dan terbentuk gumpalan.

Komponen minyak yang tidak dapat larut di dalam air akan mengapung dan menyebabkan air laut berwarna hitam. Kecepatan penyebaran akan bergantung pada kecepatan angin, arus laut dan jenis minyak. Selain itu penyebaran minyak yang ada di perairan semakin bertambah luas disebabkan adanya proses difusi minyak. Keberadaan minyak di perairan mengalami penurunan disebabkan oleh terjadinya proses evaporasi dan dispersi minyak yang disebabkan oleh kondisi lingkungan (Krisdiantoro, 2012).

Menurut Dursma dan Marchand (1974) jika arah sebaran minyak menuju pantai dan mengendap, maka minyak akan terdegradasi dengan sendirinya di pantai dan berdampak negatif bagi ekosistem pantai. Beberapa komponen minyak tenggelam dan terakumulasi di dalam sedimen sebagai deposit hitam pada pasir dan batuan-batuan di pantai. Komponen hidrokarbon yang bersifat toksin dapat berpengaruh pada reproduksi, perkembangan, pertumbuhan dan perilaku biota laut terutama pada plankton bahkan dapat mematikan ikan dan organisme laut lainnya.

Peristiwa tumpahan minyak di anjungan minyak Montara di Laut timor terjadi pada tanggal 21 Agusts 2009 dan berlangsung selama 74 hari. Tumpahan minyak ini terjadi karena adanya ledakan anjungan sumur minyak Montara. Sebaran minyak yang tumpah diperkirakan menyebar pada areal seluas $10.842 .81 \mathrm{~km}^{2}$ yang terbawa oleh angin, gerakan pasang surut, dan arus (AMSA 2010).

\section{Reflectance W-E}

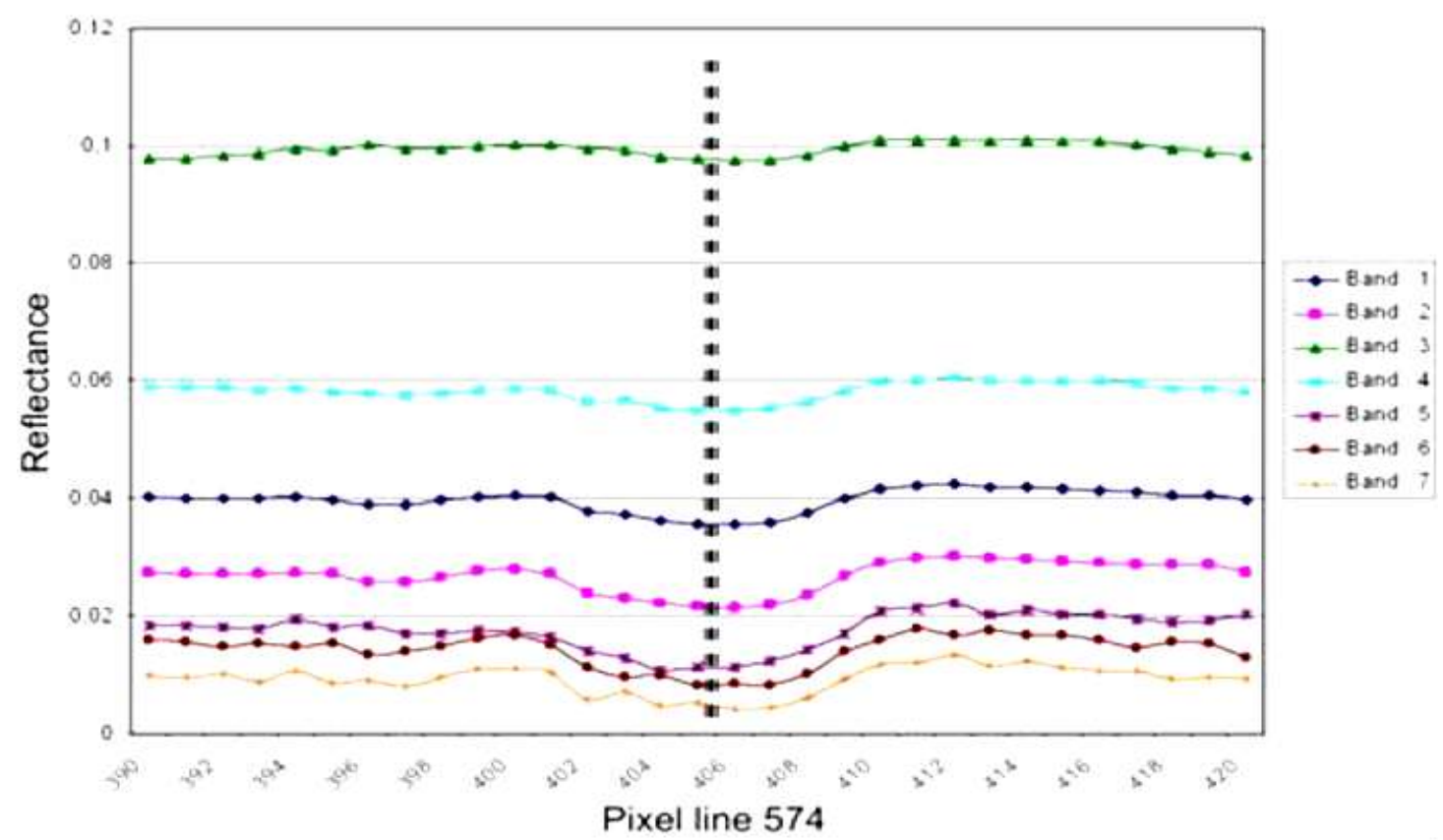

Gambar 1. Nilai reflektansi tumpahan minyak di Teluk Cagliari (Dessi, 2008) 
Berdasarkan penelitian Lumban Gaol (2009) dengan citra radar pada tanggal 30 Agustus 2009 menunjukkan secara jelas distribusi oil spill di perairan Timor hingga Australia. Selain Radar, sensor Moderate Resolution Imaging Spectrometer (MODIS) juga dapat digunakan untuk mendeteksi tumpahan minyak di perairan laut. MODIS merupakan salah satu sensor yang terdapat pada satelit Terra dan Aqua. Data dari hasil satelit ini dapat meningkatkan pemahaman kita tentang dinamika dan proses alam yang terjadi di darat maupun lautan.

Beberapa penelitian dengan menggunakan citra MODIS untuk mendeteksi tumpahan minyak di laut telah banyak dilakukan oleh peneliti-peneliti dengan menggunakan berbagai algoritma yang berbeda. Berdasarkan penelitian Alesheikh (2011), deteksi tumpahan minyak di Teluk Meksiko dengan citra MODIS menunjukkan bahwa penggunaan algoritma rasio kanal dibandingkan dengan metode PCA menunjukkan hasil yang lebih baik dalam mendeteksi tumpahan minyak. Sementara itu, hasil penelitian Dessi (2008) yang mendeteksi tumpahan minyak di Teluk Cagliari dengan MODIS menunjukkan bahwa tumpahan minyak memiliki reflektansi yang lebih besar dibandingkan dengan air laut (Gambar 1), terutama pada kisaran spektral kanal biru (band 3 MODIS).

Peristiwa tumpahan minyak di Laut Timor juga berhasil terekam oleh sensor MODIS. Beberapa penelitian yang dilakukan untuk mendeteksi tumpahan minyak tersebut menggunakan citra MODIS dengan berbagai algoritma, diantaranya Oil Spill Index, Fluorescence Index, PCA, NDVI.

Penelitian ini bertujuan untuk mendeteksi tumpahan minyak dengan citra MODIS menggunakan beberapa algoritma dan melihat perbedaan visualisasi yang dihasilkan.

\section{METODOLOGI}

Lokasi yang diteliti yaitu daerah tercemar akibat tumpahan minyak dari Anjungan Montara di laut Timor pada posisi geografi $11^{\circ} 0^{\prime} 0^{\prime} \mathrm{LS}$ - $14^{\circ} 0^{\prime} \mathrm{O}^{\prime} \mathrm{LS}$ dan $115^{\circ} 0^{\prime} 0$ " BT - 129 $0^{\circ} 0^{\prime}$ "BT (Gambar 2).
Bahan yang digunakan dalam penelitian ini adalah citra MODIS, data angin, data arus dan data lapang. Citra MODIS level $1 \mathrm{~b}$ yang digunakan adalah yang diunduh dari situs http://disc.gsfc.nasa.gov. Citra MODIS level 1b yang diunduh adalah yang tidak tertutup awan pada daerah yang terdapat tumpahan minyak. Data angin ini diunduh dari situs http://data-port al.ecmwf.int. Data arus tersebut dapat diunduh dari http://www.oscar.noaa.gov.

Alat yang digunakan dalam pengolahan data adalah satu set komputer dengan perangkat lunak ErMapper 6.4, Envi 4.5, ArcGis 10, HegWin 2.11, Surfer 9 dan Ms. Excel 2007, serta perangkat lunak lain yang mendukung penelitian ini. Citra dengan format * ${ }^{*}$ hdf sebelumnya harus dikonversikan terlebih dahulu kedalam bentuk format *.tif dengan menggunakan software HEG WIN 2.11.

Citra yang sudah berformat *.tif kemudian diolah dengan software ErMapper, untuk dilakukan koreksi atmosferik. Koreksi tersebut untuk menghilangkan pengaruh atmosfer, metode yang digunakan adalah histogram adjustment. Kemudian dilakukan citra dengan berbagai algoritma. yaitu Fluorescence Index, Oil Spill Index, SST Callison, PCA, dan NDVI .

\subsection{Fluorecence Index}

Menurut Dessi (2008) produk hidrokarbon memiliki sifat fluoresensi dimana memancarkan cahaya ketika terkena ultraviolet atau beberapa sinar tampak. Sehingga dengan algoritma fluorescence Index dapat diketahui keberadaan senyawa hidrokarbon. Algoritma fluorescence index dapat dituliskan sebagai berikut:

$$
\text { Fluorescence Index }=\frac{\text { Blue-Red }}{\text { Blue+Red }}
$$

Citra MODIS spektrum biru (blue) berada pada kanal 3 dan spektrum merah (red) terdapat pada kanal 1. Semakin tinggi komponen hidrokarbon maka nilai fluorescence index juga akan semakin besar.

\subsection{Oil Spill Index}

Menurut Alesheikh (2011) algoritma Oil Spill Index memiliki prinsip rasio kanal, yaitu membandingan selisih dan jumlah dari kanal 4 dan kanal 1 dari 
MODIS yang dinormalisasikan dengan kanal 3 (B3) sehingga menghasilkan nilai yang berbeda antara minyak dan bukan minyak. Algoritma tersebut dapat dituliskan sebagai berikut:

$$
\text { OilSpillIndex }=\frac{\{(\mathrm{B} 4 / \mathrm{B} 3)-(\mathrm{B} 1 / \mathrm{B} 3)\}}{\{(\mathrm{B} 4 / \mathrm{B} 3)+(\mathrm{B} 1 / \mathrm{B} 3)\}}
$$

\subsection{SST-Callison}

Kanal pada MODIS yang digunakan untuk algoritma SST adalah kanal 31dan 32 pada rentang nilai spektral thermal infrared. Setiap kanal-kanal ini kemudian akan dikonversi nilai digital number-nya menjadi nilai radiansi dengan rumus sebagai berikut:

$\mathrm{L}_{\mathrm{i}}=$ radiance_scales $\left(\mathrm{SI}_{\mathrm{i}}\right.$-radiance_offsets $)$

\section{Dimana:}

$\mathrm{L}_{\mathrm{i}}$ : Radiansi kanal $i$

$\mathrm{SI}_{\mathrm{i}}$ : Skala integer kanal $i$ (digital number)

Nilai radiance_scales dan radiance_offsets didapatkan dari atribut yang ada pada fail hdf disesuaikan dengan kanal yang akan di kalibrasi. Setelah menghitung nilai radiansi, selanjutnya dilakukan perhitungan suhu kecerahan dengan menggunakan persamaan Planck. Adapun persamaan Planck sebagai berikut:

$$
\mathrm{TB}=\frac{\mathrm{C} 2}{\lambda_{(\mathrm{i})} \ln \left(\left(\mathrm{C} 1 / \lambda_{(\mathrm{i})}^{5} \mathrm{~L}_{\lambda_{(\mathrm{i})}}\right)\right)+1}
$$

Dimana,

TB : suhu kecerahan $\left({ }^{\circ} \mathrm{K}\right)$

C2 : konstanta radiansi kedua $\left(1.493 \times 10^{4} \mathrm{~K} \mathrm{\mu \textrm {m }}\right)$

C1 : konstanta radiasi pertama $\left(1.1911 \times 10^{8} \mathrm{~W} \mathrm{M}^{-2} \mathrm{sr}^{-2}\left(\mu \mathrm{m}^{-1}\right)^{-4}\right)$

$\mathrm{L} \lambda(\mathrm{i})$ : nilai radiansi kanal ke-i $\left(\mathrm{WM}^{-2} \mu \mathrm{m}\right.$ sr)

$\lambda(\mathrm{i})$ : nilai tengah panjang gelombang kanal ke-i $(\mu \mathrm{m})$

Setelah diketahui suhu kecerahan dari tiap kanal,selanjutnya dilakukan perhitungan suhu permukaan laut dengan menggunakan algoritma Callison (1989) sebagai berkut:

$$
\operatorname{SPL}\left({ }^{\circ} \mathrm{C}\right)=\left[\left(1,0351 * T b_{31}\right)+\left(3,046 *\left(T b_{31}-T b_{32}\right)\right)\right]-10,93-273
$$

\section{Dimana:}

$T b_{31}$ : suhu kecerahan kanal 31

$T b_{32}$ : suhu kecerahan kanal 32

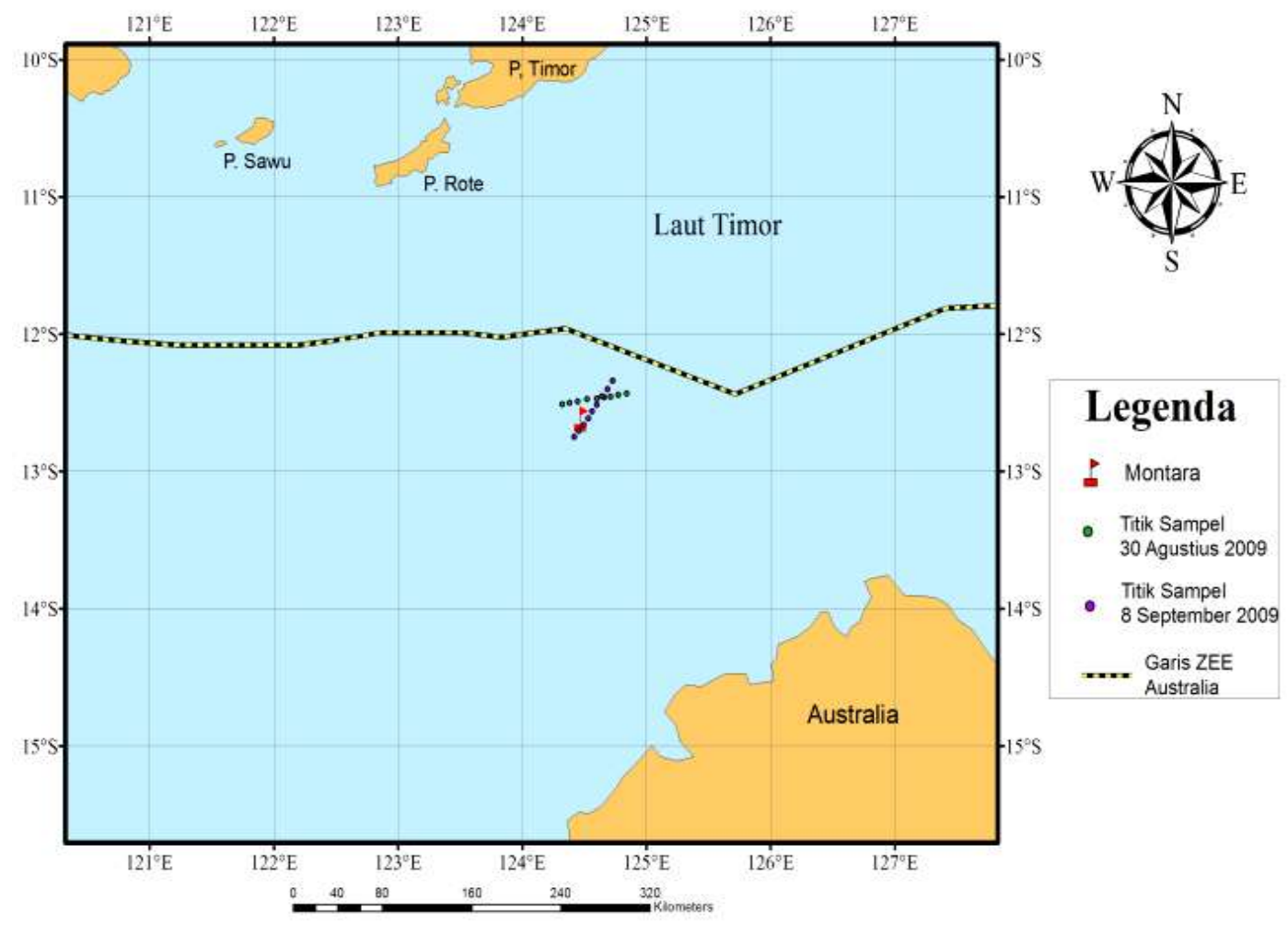

Gambar 2. Peta lokasi penelitian 


\subsection{PCA}

PCA akan menghilangkan gangguan pada data dan melinearisasikan piksel dengan korelasi tinggi antar saluran. Transformasi ini akan menghasilkan perbedaan visual dan kontras yang lebih baik antar obyek. PCA akan mentranformasikan citra untuk mendapatkan komponen penting representatif baru yang saling tidak berkorelasi. Komponen penting ini direpresentasikan dalam vektor nilai eigen.

Komponen penting ini didapatkan dengan transformasi forward. Secara matematis dijelaskan sebagai berikut:

$$
\left[\begin{array}{l}
\mathrm{PC} 1 \\
\mathrm{PC} 2 \\
\mathrm{PCn}
\end{array}\right]=\left[\begin{array}{crcc}
\mathrm{V} 11 & \mathrm{~V} 21 & \cdots & \mathrm{Vn} 1 \\
V 12 & \mathrm{~V} 22 & \cdots & \mathrm{Vn} 2 \\
\vdots & \vdots & & \vdots \\
\mathrm{V} 1 \mathrm{n} & \mathrm{V} 2 \mathrm{n} & \cdots & \mathrm{Vnn}
\end{array}\right]\left[\begin{array}{c}
\mathrm{DN}_{\mathrm{MS} 1}^{1} \\
D N_{M S 2}^{1} \\
\vdots \\
\mathrm{DN} \\
\mathrm{MSn}
\end{array}\right]
$$

Dengan $\mathrm{DN}^{1}{ }_{\mathrm{MS}}$ adalah digital number dari citra input multispectral. PC1 adalah komponen pertama, dan matriks transformasi $v$ terdiri dari vektor-vektor eigen yang diurutkan berdasarkan eigennya.

Vektor eigen yang memiliki nilai eigen tertinggi merupakan komponen penting pertama (PC1). PC1 ini yang akan digantikan oleh data citra pankromatik beresolusi spasial tinggi, yang sebelumnya direntangkan agar memiliki rataan yang menyamai PC1 (Smith L, 2002).

Transformasi dari PCA forward secara otomatis sudah ada difitur transformation pada software ENVI. Pada penelitian ini digunakan kanal 1 dan kanal 3 sebagai masukan untuk transformasi PCA.

\subsection{NDVI}

Indeks vegetasi adalah pengukuran kuantitatif berdasarkan nilai digital dari data penginderaan jauh yang digunakan untuk mengukur biomassa atau intensitas vegetasi di permukaan bumi. Algoritma NDVI sudah sering digunakan untuk pemetaan sebaran klorofil, terumbu karang dan juga mangrove.

Nilai NDVI berkisar antara - 1 hingga +1 . Nilai NDVI yang rendah (negatif) menunjukan tingkat vegetasi yang rendah seperti awan, air, tanah kosong, bangunan, dan unsur nonvegetasi hijau yang tinggi (positif) menunjukan tingkat vegetasi hijau yang tinggi.Oleh karena itu, nilai NDVI sebanding dengan kuan- titas tutupan vegetasinya (Lillesand and Kiefer. 1990).

Pada dasarnya NDVI mampu meminimalisir kesalahan atmosferik seperti efek haze (blur) dan mampu membedakan antara tubuh air yang bersubstrat dengan tubuh air yang tidak bersubstrat dengan cukup baik. Adapun rumus NDVIsebagai berikut:

$$
\text { NDVI }=\frac{\text { Near Infrared }- \text { Red }}{\text { Near Infrared }+ \text { Red }}
$$

Pada sensor MODIS spektrum Near Infrared berada pada kanal 2 dan spektrum merah terdapat pada kanal 1 (Deveson, 2005).

\subsection{Membandingkan Nilai Piksel Hasil Algoritma}

Setelah dari kelima algoritma tersebut didapatkan, kemudian dilakukan perbandingan terhadap daerah yang terkena minyak dan tidak terkena minyak. Hasil kelima algoritma tersebut diplotkan kedalam bentuk grafik sehingga membentuk signature dari tumpahan minyak yang akan dijadikan acuan dalam uji akurasi.

\subsection{Uji Akurasi}

Uji akurasi dilakukan untuk mengetahui algoritma mana yang baik digunakan untuk melihat tumpahan minyak di laut dengan menggunakan citra MODIS. Uji akurasi ini menggunakan data lapang dari Applied Ecology Solutions (AES) yang bekerja sama dengan World Wide Fund (WWF). Untuk mengetahui lokasi pada citra MODIS merupakan tumpahan minyak atau bukan, berdasarkan pada signature atau profil minyak dari hasil grafik nilai piksel pada daerah tumpahan minyak dan bukan minyak. Perhitungan persen nilai akurasi adalah sebagi berikut:

$\%$ Akurasi $=\frac{\text { Jumlah data yang sesuai }}{\text { Total Data }} \times 100$

\subsection{Pengolahan Data Angin}

Data angin digunakan untuk melihat pengaruh angin terhadap sebaran tumpahan minyak. Langkah pertama yang dilakukan adalah membuka data arus berformat *.nc dengan menggunakan software ODV untuk mengekstrak datanya kedalam format *.txt. Setelah itu data dengan format *.txt di buka 
dengan menggunakan software Microsoft Excel sehingga akan didapatkan nilai dari komponen angin zonal (U) dan meridional (V) yang merupakan bagian dari vektor dengan arah vertikal dan horizontal. Nilai U dan $\mathrm{V}$ ini kemudian dikonversi kedalam kecepatan. Nilai U dan $\mathrm{V}$ ini kemudian di griding dengan perangkat lunak Surfer 9. Griding hasil nilai $\mathrm{U}$ dan $\mathrm{V}$ kemudian diplotkan kedalam lokasi daerah tumpahan minyak. Kemudian dimasukan colour scaling berupa kecepatan dari angin.

\subsection{Pengolahan Data Arus}

Data arus yang diunduh adalah berformat *.nc terlebih dahulu diekstrak ke dalam format *.txt dengan meggunakan software ODV. Setelah itu data dengan format *.txt dibuka dengan menggunakan software Microsoft Excel sehingga akan didapatkan nilai dari komponen angin zonal (U) dan meridional (V) yang merupakan bagian dari vektor dengan arah vertical dan horizontal. Nilai U dan V ini kemudian di griding dengan menggunakan soft-ware Surfer 9 dan setelah itu diplotkan ke dalam lokasi daerah tumpahan mi-nyak.

\section{HASIL DAN PEMBAHASAN}

\subsection{Perbedaan visualisasi dan profil indeks setiap algoritma}

Citra yang diolah untuk melihat perbandingan penampakan hasil lima algoritma adalah citra MODIS tanggal 30 Agustus 2009 dan 8 September 2009. Hasil yang didapatkan menunjukan, penampakan kecerahan yang berbeda-beda pada daerah yang terkena dan tidak terkena tumpahan minyak.

Terlihat pada Gambar 3 dan 4 bahwa citra dengan algoritma PCA dan NDVI memiliki warna yang lebih gelap pada daerah terkena minyak dibandingkan yang tidak terkena tumpahan minyak namun kontras antara tumpahan minyak dengan badan air yang ditampilkan dari kedua algoritma ini berbeda.Tumpahan minyak lebih terlihat dengan menggunakan algoritma NDVI.

Algoritma PCA dan NDVI menunjukan nilai yang lebih kecil pada daerah tumpahan minyak seperti pada stasiun 5, 6, dan 7 tanggal 30 Agustus 2009 dan stasiun 4, 5, dan 6 tanggal 8 September 2009. Menurut Alesheikh
(2011) penggunaan transformasi PCA ini dalam penginderaan jauh menghasilkan suatu citra yang lebih mudah untuk mengenali suatu obyek tertentu dibandingkan citra aslinya. Sedangkan NDVI akan menghasilkan garis batas yang tegas antara laut dalam dengan tubuh air yang dangkal dan bersubstrat (Wicaksono, 2008).

Hasil algoritma Oil spill index dan flourcence Index yang ditunjukan berturut-turut pada Gambar 5 dan 6 menunjukan pada daerah terkena tumpahan minyak memiliki warna yang lebih cerah dibandingkan pada daerah tidak terkena minyak, kontras kecerahan yang ditampilkan kedua algoritma antara tumpahan minyak dan bukan tumpahan minyak lebih terlihat jelas pada algoritma fluorescence index.

Menurut Alesheikh (2011) oil spill index mampu memberikan penampaan yang jelas pada daerah tumpahan minyak dan memberikan kontras di daerah tersebut, karena algoritma ini menggunakan panjang gelombang pendek seperti biru yang mempunyai kemampuan lebih baik dalam mengidentifikasi material biogenic (Hu et al., 2003). Pada gambar 5 terlihat bahwa di titik sampel yang terkena tumpahan minyak memiliki hasil nilai Oil spill index yang lebih tinggi di bandingkan pada daerah yang bukan merupakan tumpahan minyak.

Berdasarkan Gambar 6 dapat diketahui bahwa nilai fluorescence index lebih tinggi pada daerah perairan yang terkena tumpahan minyak. Menurut Harto et al, (2009) tumpahan minyak mengandung komponen hidrokarbon yang mempunyai karakteristik dari fluorescence, lalu hubungan unsur hidrokarbon dengan komponen minyak adalah berbanding lurus. Dapat dikatakan pula bahwa memang benar pada stasiun yang terkena tumpahan minyak merupakan komponen minyak karena nilai fluorescence index pada stasiun tersebut lebih tinggi dibandingkan stasiun lain. Penampakan pada citra juga menunjukan bahwa pada daerah tersebut merupakan daerah tumpahan minyak.

Hasil algoritma SST yang ditunjukan pada Gambar 7 tidak menunjukan perbedaan antara daerah yang terkena tumpahan minyak dan tidak terkena tumpahan minyak. Namun jika dilihat dari lokasi tumpahan minyak yang se- 
benarnya berada, terlihat bahwa pada wilayah terjadinya tumpahan minyak menunjukan kisaran suhu yang lebih tinggi dibandingkan daerah diluar tumpahan minyak. Hal ini kemungkinan disebabkan oleh kalor jenis minyak yang lebih kecil dibandingkan dengan air laut. Kalor jenis ini sangat mempe- ngaruhi perubahan suhu suatu zat, jika semakin kecil kalor jenis yang dimiliki oleh suatu zat maka perubahan suhu zat tersebut akan semakin cepat. Kalor jenis minyak memiliki nilai sebesar $1-2$ $\mathrm{kJ} / \mathrm{kg} . \mathrm{K}$ bergantung jenis minyaknya sedangkan air laut memiliki nilai kalor jenis sebesar $3.93 \mathrm{~kJ} / \mathrm{kg} . \mathrm{K}$.
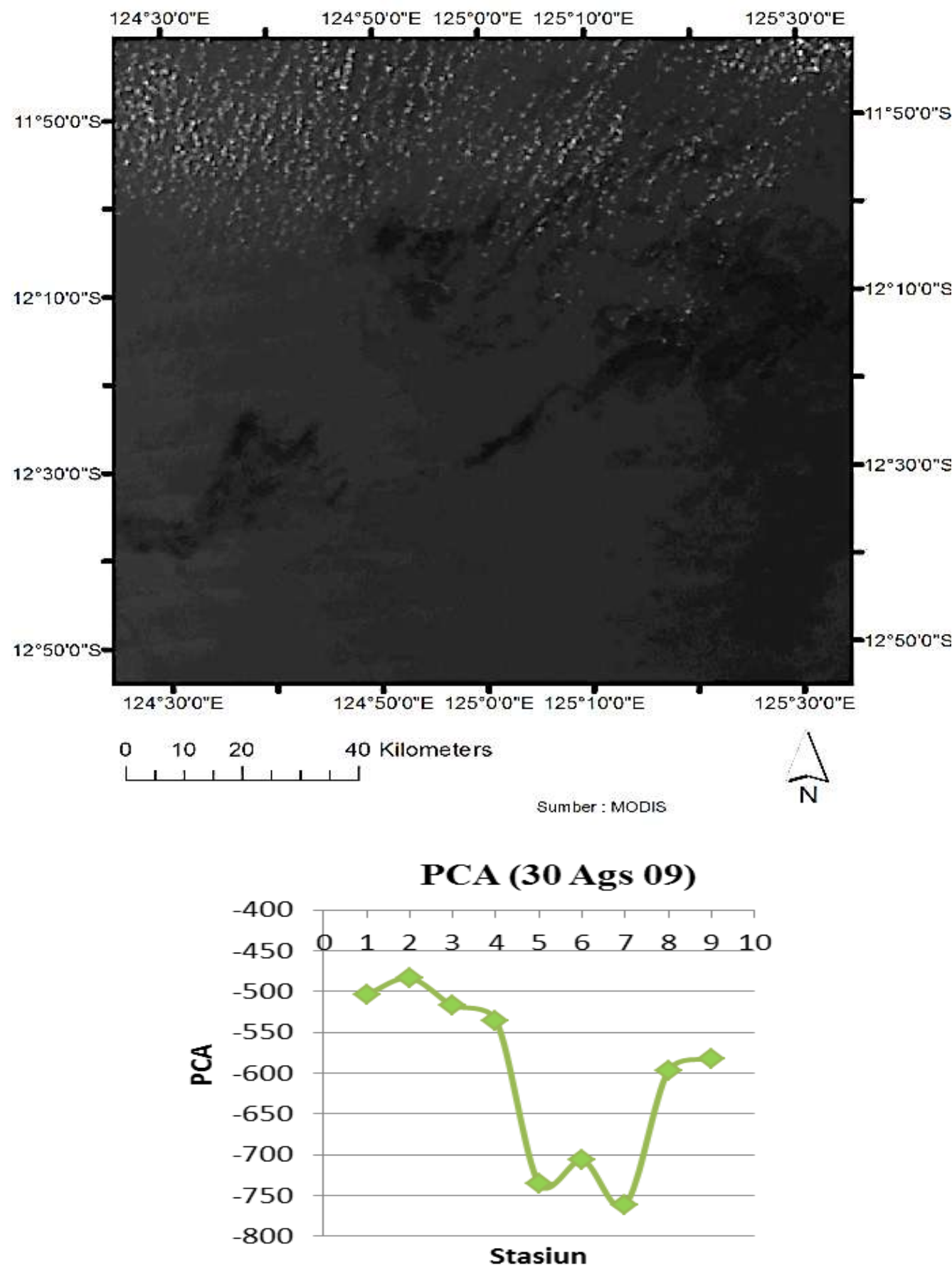

(a)

Gambar 3. (a). Hasil pemrosesan dengan algoritma PCA 30 Agustus 2009 

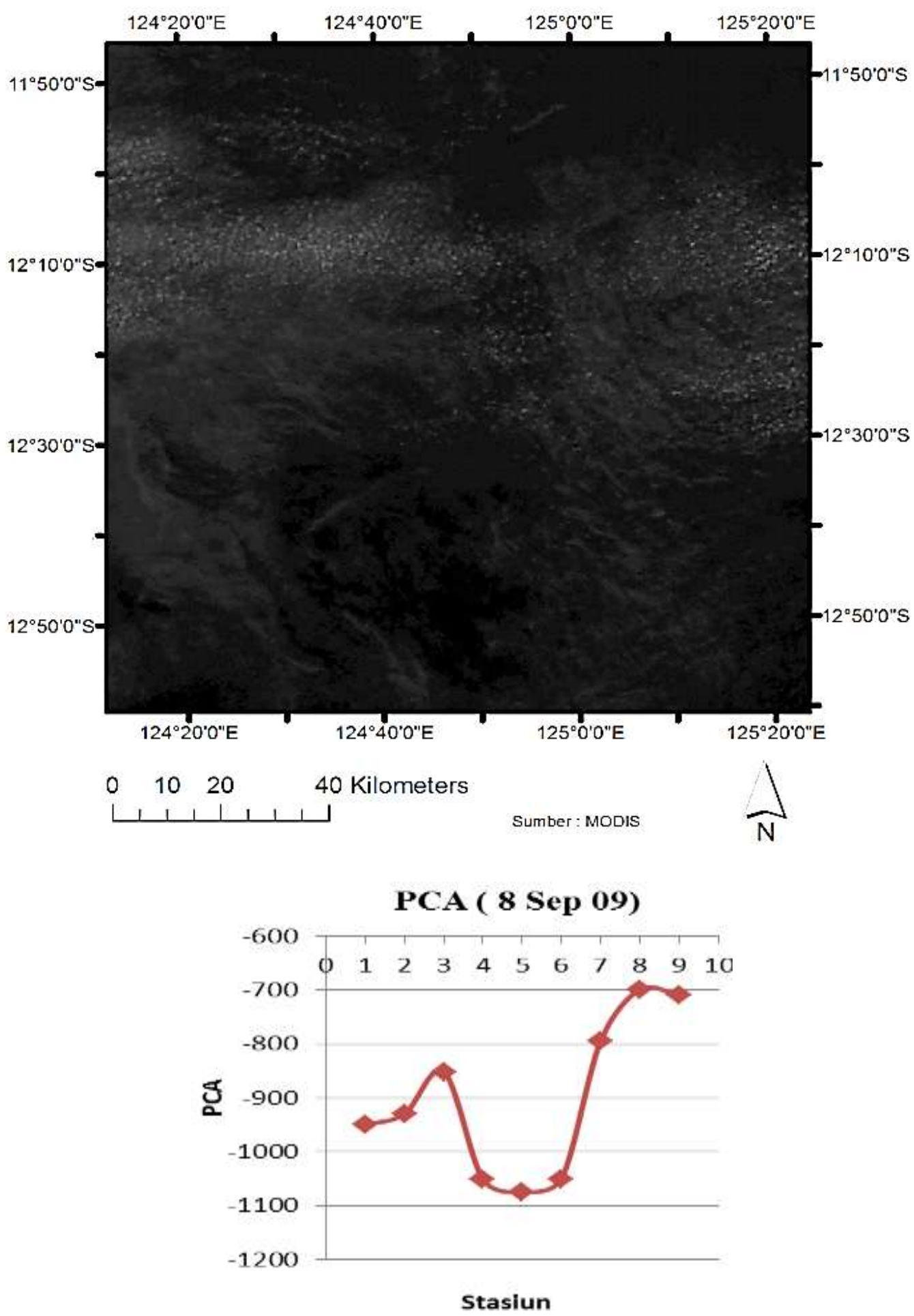

(b)

Gambar 3. (b). Hasil pemrosesan dengan algoritma PCA 8 September 2009 

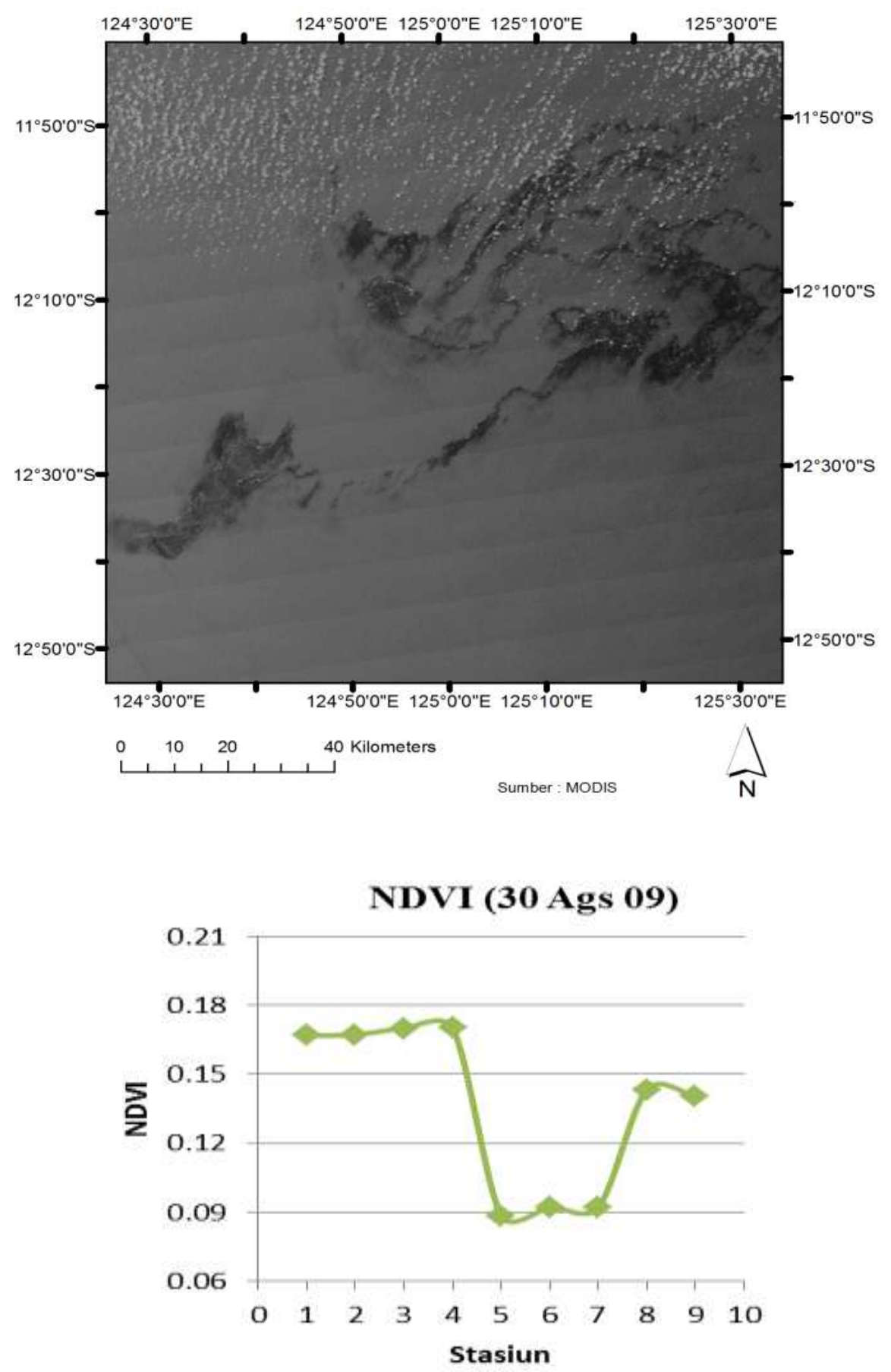

(a)

Gambar 4. (a). Hasil pemrosesan dengan algoritma NDVI30 Agustus 2009 

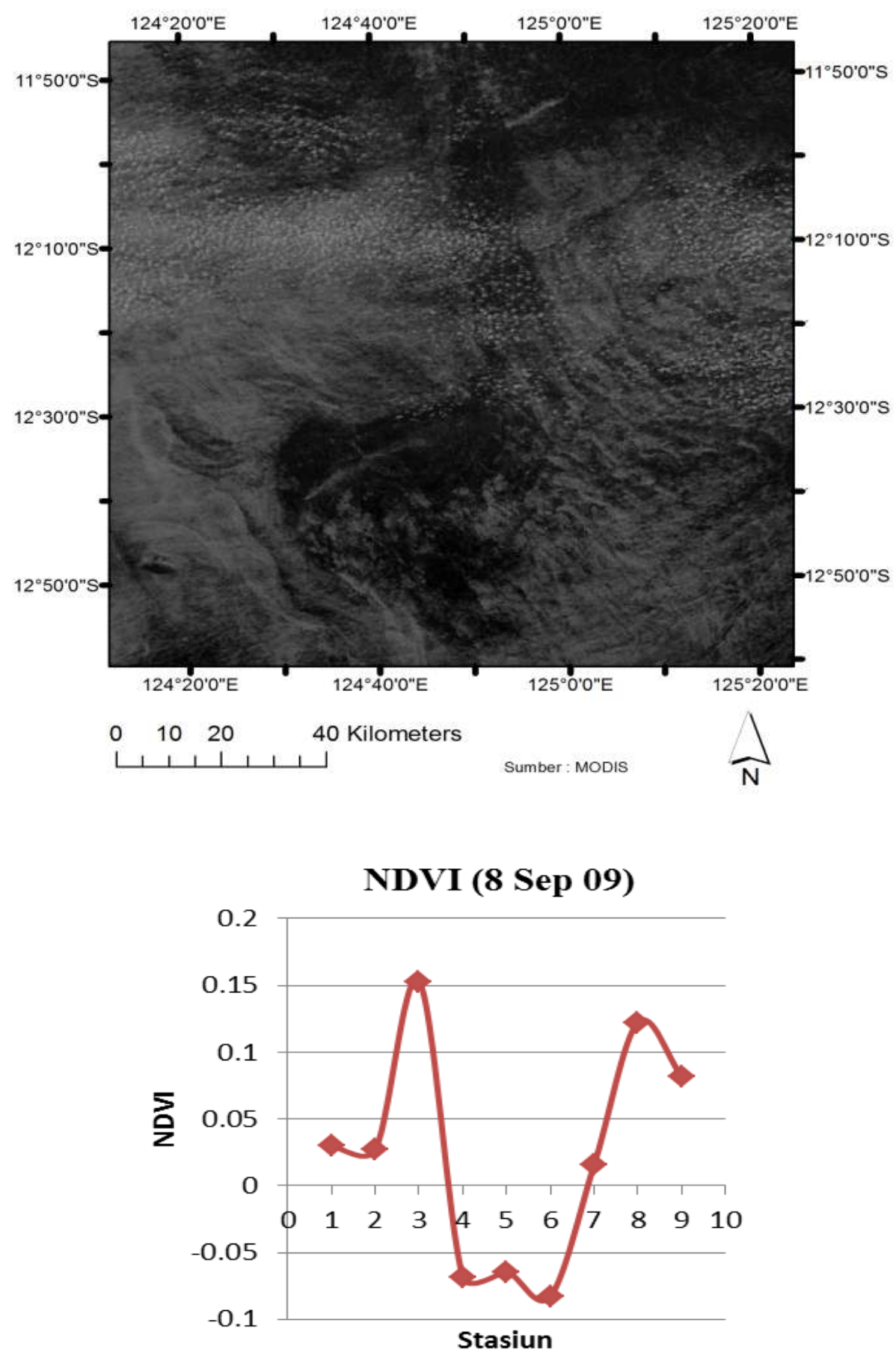

(b)

Gambar 4. (b). Hasil pemrosesan dengan algoritma NDVI 8 September 2009 

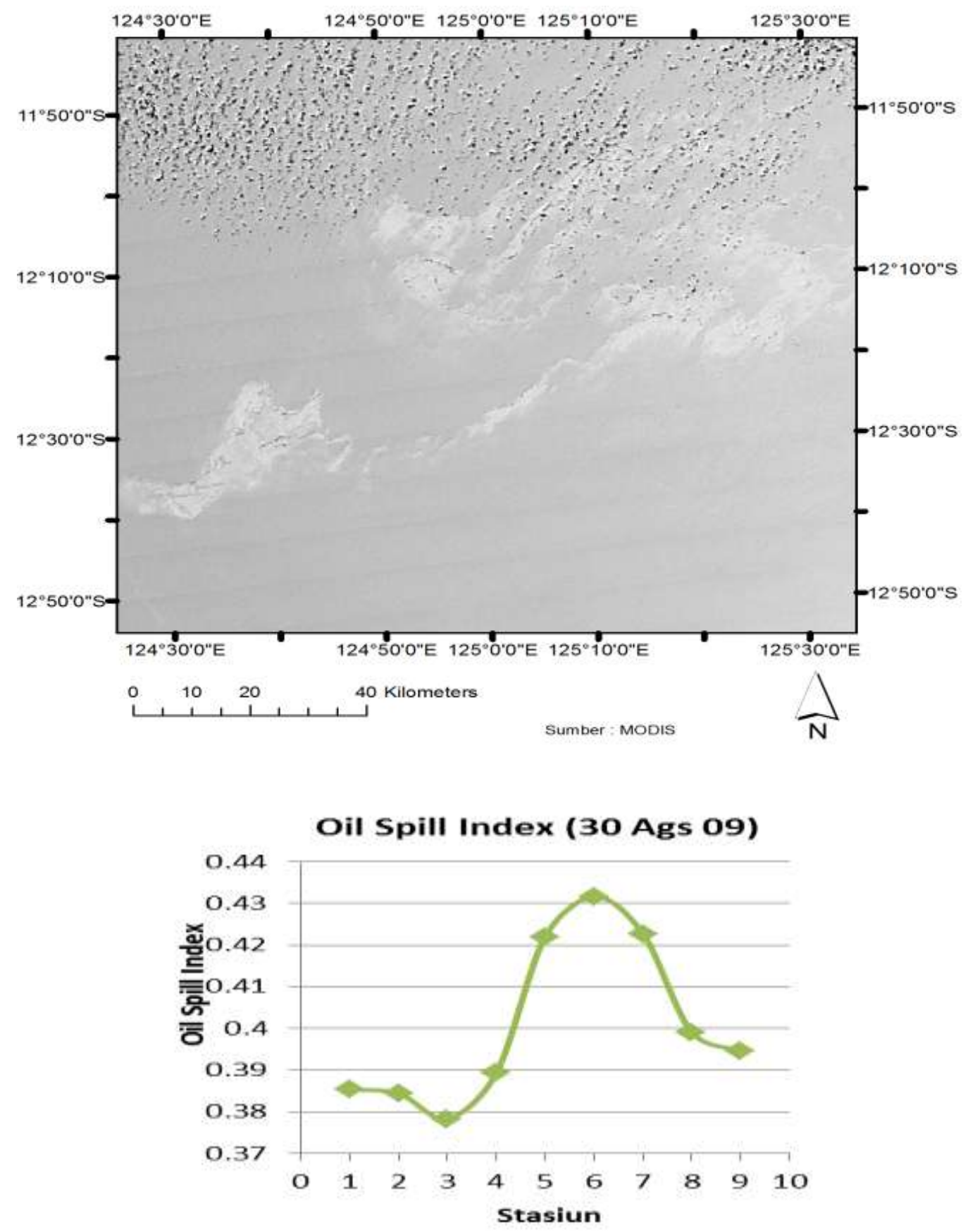

(a)

Gambar 5. (a). Hasil pemrosesan dengan Algoritma Oil Spill Index 30 Agustus 2009 

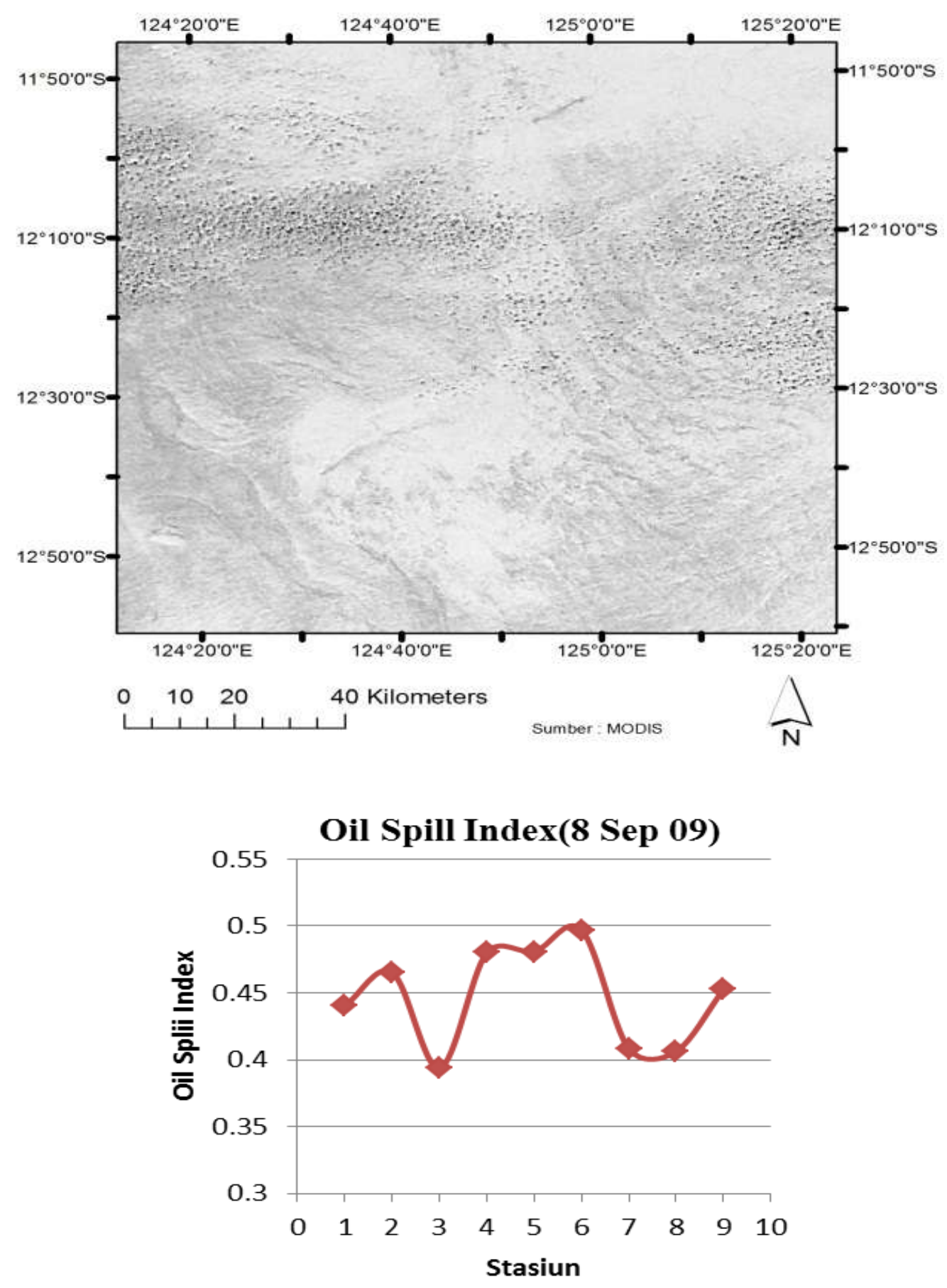

(b)

Gambar 5. (b). Hasil pemrosesan dengan Algoritma Oil Spill Index 8 September 2009 


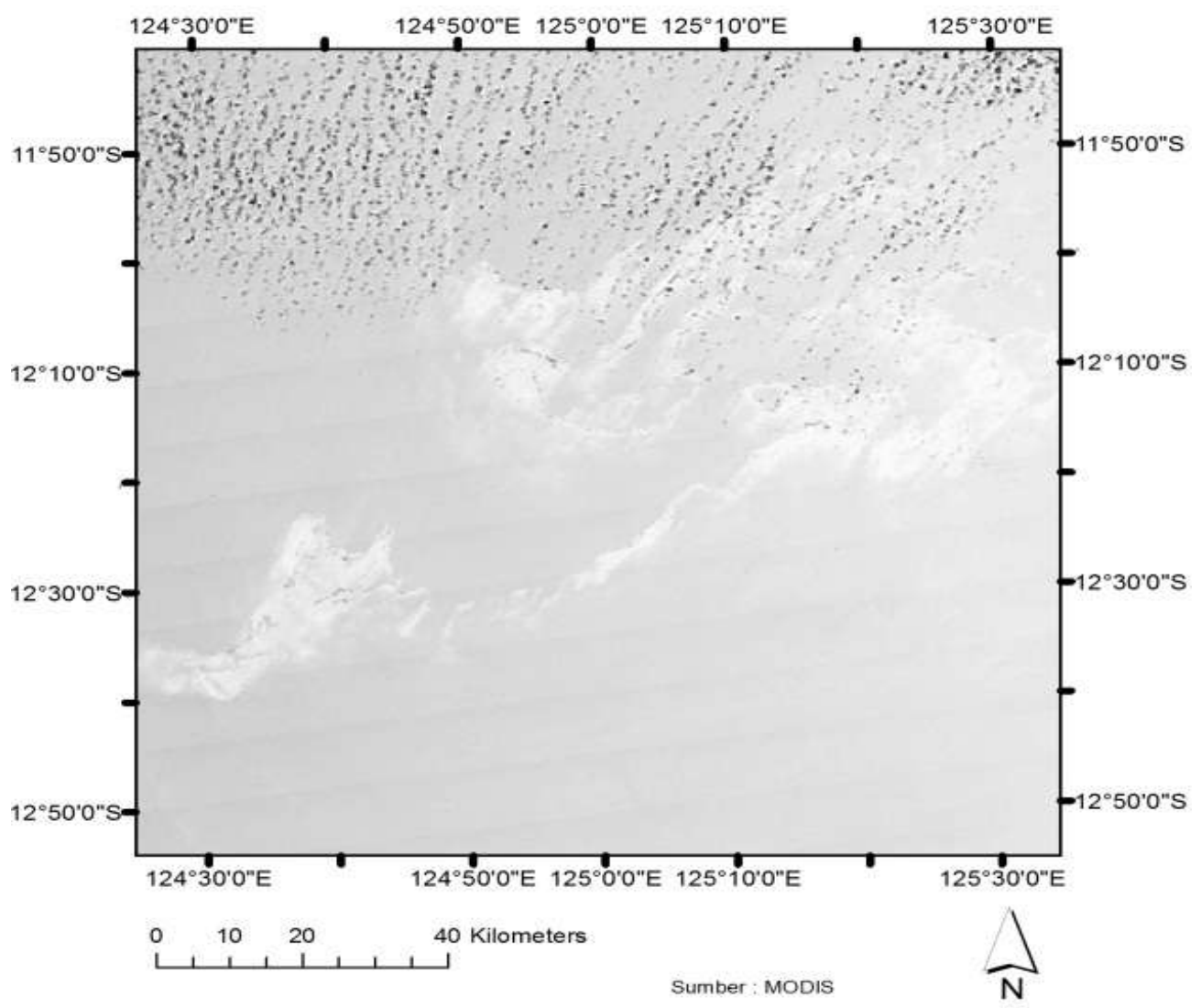

Flourecence Index (30 ags 09)

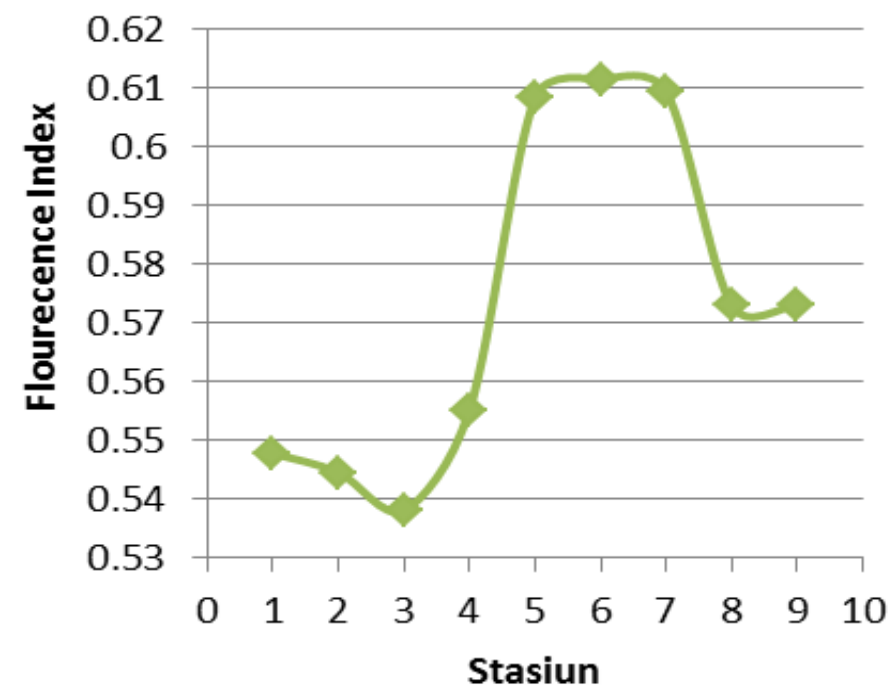

(a)

Gambar 6. (a). Hasil pemrosesan dengan Algoritma Fluorescence Index 30 Agustus 2009 


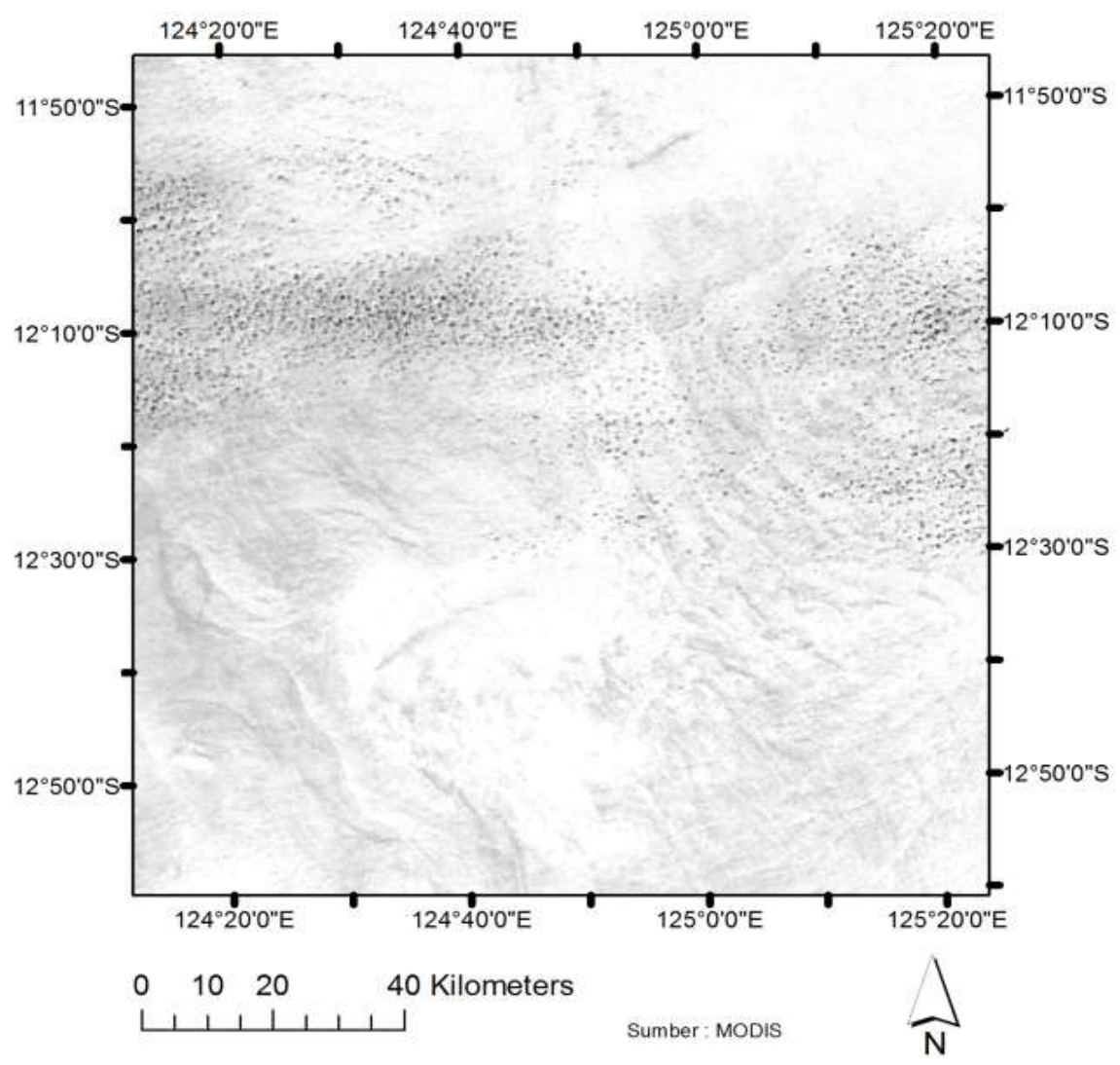

Flourecence Index (8 Sep 09)

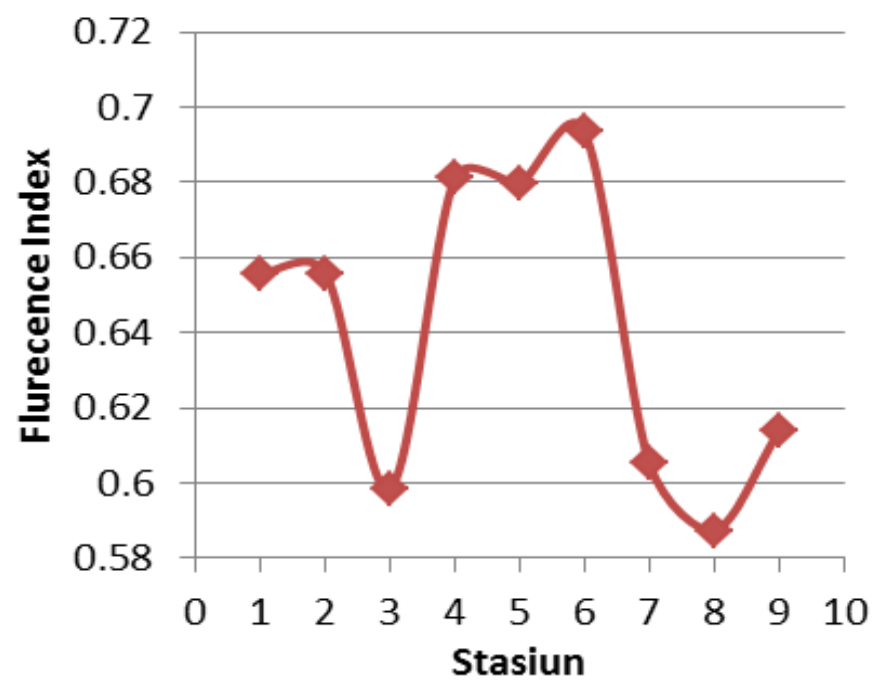

(b)

Gambar 6.(b). Hasil pemrosesan dengan Algoritma Fluorescence Index 8 September 2009 


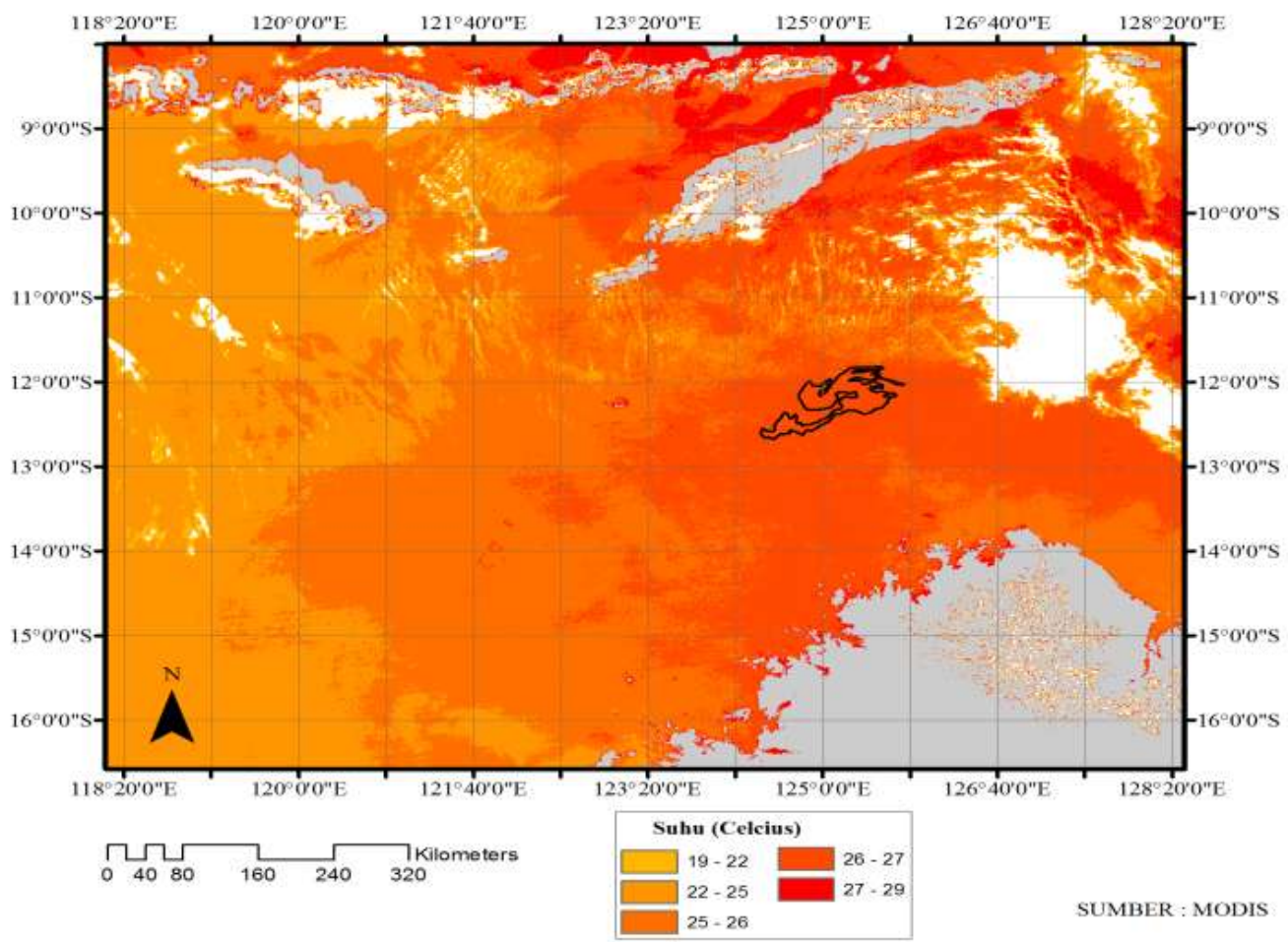

(a)

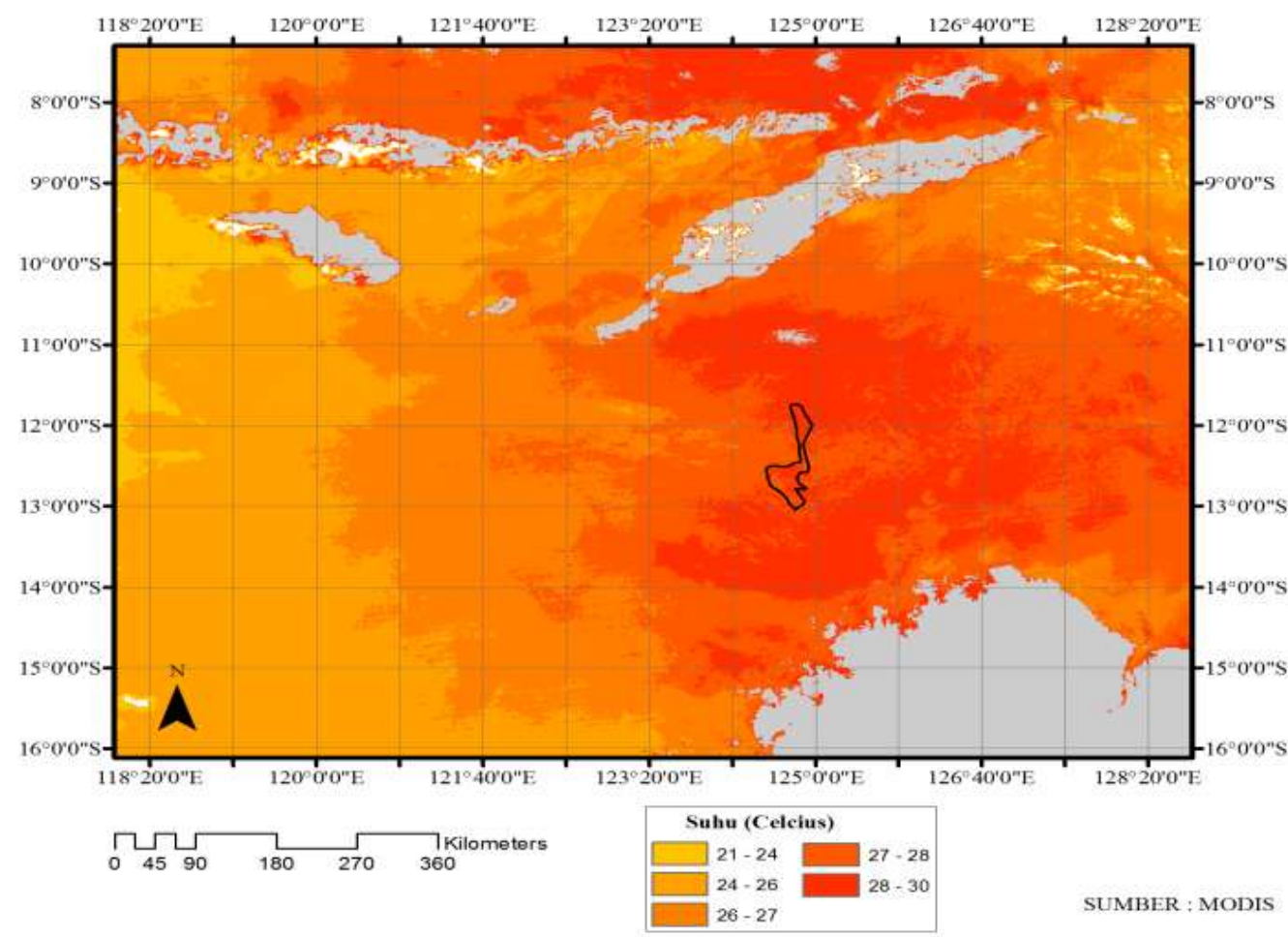

(b)

Gambar 7. SST hasil algoritma Callison dari citra MODIS, (a) 30 Agustus 2009, (b) 8 September 2009 
Menurut Paulus (2006) algoritma SST Callison untuk citra MODIS tepat digunakan di wilayah Laut Timor. Jika dibandingkan dengan data SST yang dimiliki oleh citra modis level 3 yang diekstrak melaui software SeaDas, maka didapatkan hubungan korelasi linear yang ditunjukan pada Gambar 8 . Korelasi linear yang dihasilkan menunjukan nilai $\mathrm{R}^{2}$ masih diatas $50 \%(0.5)$. Menurut Walpole (1995) Jika nilai $\mathrm{R}^{2}$ semakin mendekati nilai $100 \%$ (1) maka terdapat tingkat hubungan yang semakin tinggi.

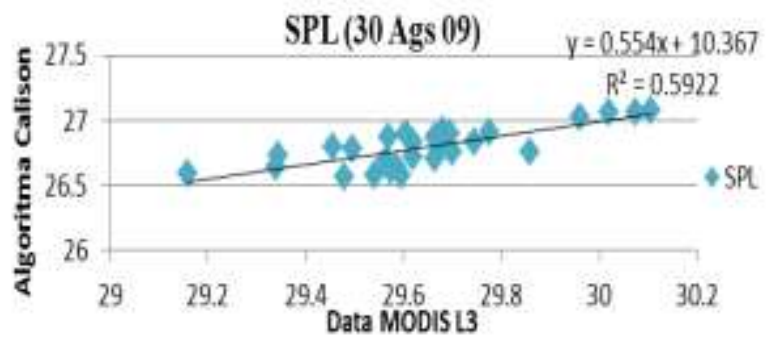

(a)

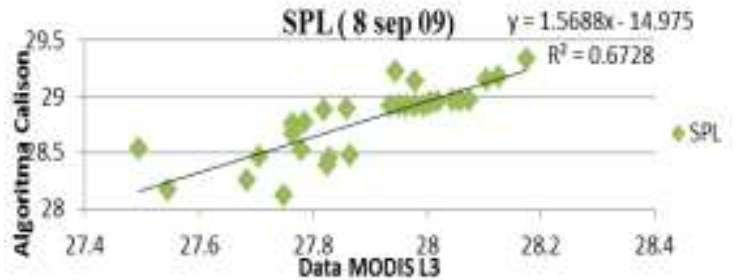

(b)

Gambar 8. Korelasi linear yang dihasilkan antara algoritma SST Calison dengan data citra MODIS level 3, (a) 30 Agustus 2009,(b) 8 September 2009

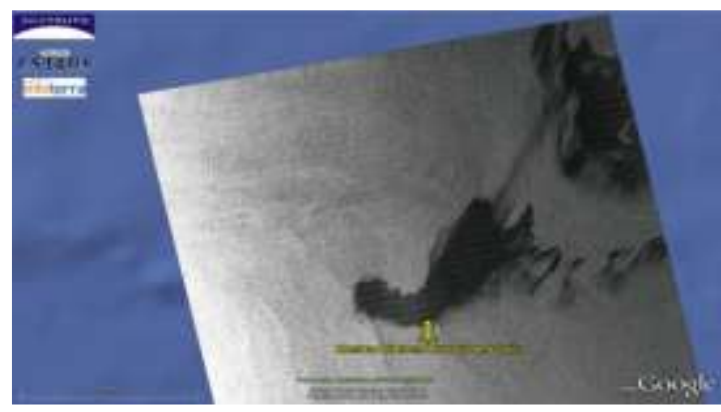

(a)

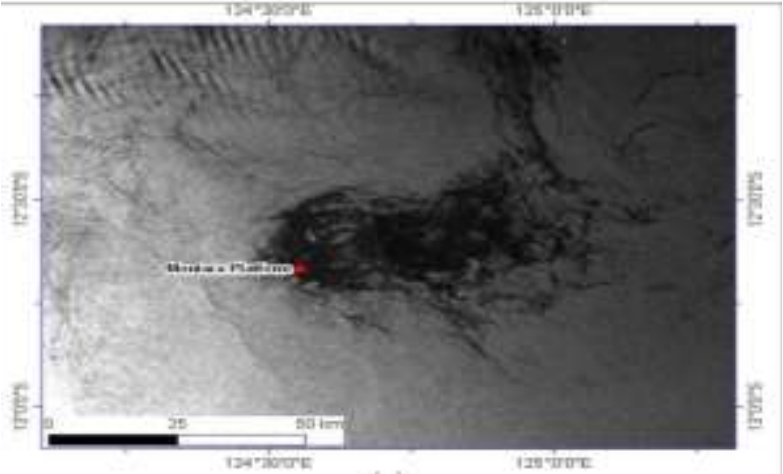

(b)

Gambar 9. Citra Radar tumpahan minyak Montara di Laut Timor, (a) 30 Agustus 2009 (Sumber: Lumban Gaol,2009), (b) 8 September 2009 (sumber: Li et.al, 2010) 
Dari ke lima algoritma yang digunakan tersebut diketahui bahwa tumpahan minyak lebih terlihat dan memiliki kontras dengan badan air adalah algoritma NDVI, sedangkan berdasarkan SST dari algoritma Callison tidak dapat menunjukan adanya penampakan tumpahan minyak, dengan demikian algoritma untuk SST dari Callison tidak dapat digunakan untuk mendeteksi tumpahan minyak.

Tumpahan minyak Montara di Laut Timor juga terekam oleh beberapa sensor RADAR (Gambar 9). Citra RADAR ini memiliki kelebihan yaitu tidak terpengaruh oleh kondisi atmosferik sehingga memiliki penampakan tumpahan minyak yang lebih jelas di laut. Walaupun begitu citra dari RADAR sulit untuk didapatkan karena menggunakan sistem order terlebih dahulu sehingga kurang efisien dan beberapa dari citra RADAR memiliki resolusi temporal yang lebih rendah dibandingkan MODIS.

\subsection{Uji akurasi algoritma terhadap tumpahan minyak}

Uji akurasi algoritma ini menggunakan data lapang dari AES (Applied Scology Solutions) yang bekerja sama dengan WWF sebagai dasar acuan lokasi tumpahan minyak sebenarnya. Data lapang terdiri dari dua jenis yaitu data pengamatan dan data pengambilan sampel tumpahan minyak (Gambar 10). Tanggal pengambilan data lapang adalah 26 September 2009 dan 27 September 2009 yang disesuaikan dengan tanggal citra MODIS. Uji akurasi ini berpedoman pada profil indeks yang didapatkan dari pemrosesan algoritma pada citra tanggal 30 Agustus 2009 dan 8 September 2009 sebelumnya. Kemudian profil indeks tiap algoritma dari citra MODIS tanggal 26 September 2009 dan 27 September 2009 disamakan dengan data lapang. Data citra yang sesuai dengan data lapang dijumlahkan dan dihitung akurasinya.

Berdasarkan hasil dari uji akurasi dapat diketahui bahwa algoritma dengan akurasi yang terbaik adalah algoritma NDVI dengan nilai total akurasi sebesar $60 \%$. Kemudian untuk algoritma Fluorescence index memiliki nilai total akurasi sebesar 46\%. Alogritma Oilspill index dan PCA memiliki nilai total akurasi yang sama yaitu sebesar $41 \%$. Nilai akurasi tersebut tidak terlalu tinggi hal ini kemungkinan disebabkan karena perbedaan waktu pengambilan data lapang dengan waktu perekaman citra sehingga tumpahan minyak dapat berpindah tempat akibat terbawa arus laut dan juga data lapang yang terbatas.

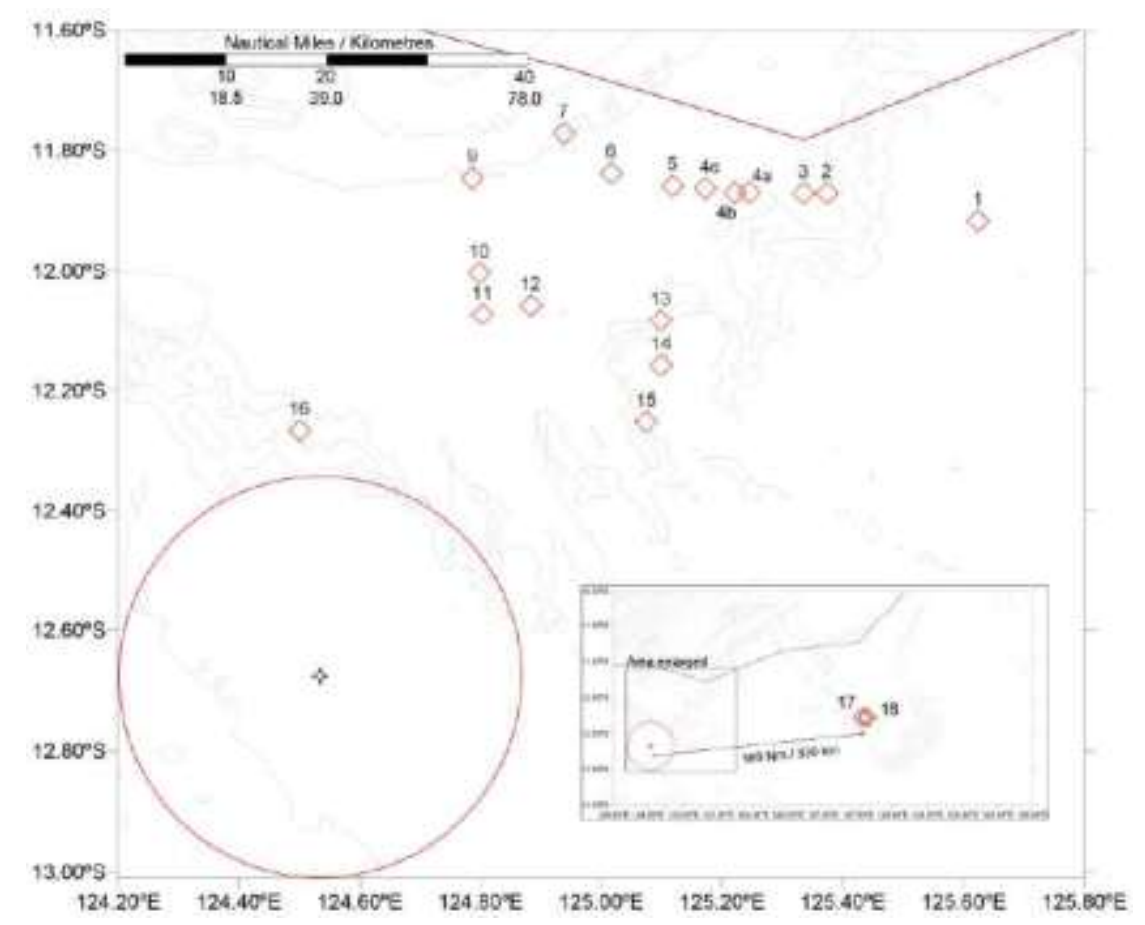

Gambar 10. Lokasi pengambilan sampel lapang oleh tim AES tanggal 26 September 2009 dan 27 September (AES, 2009) 


\subsection{Pengaruh angin terhadap pola sebaran tumpahan minyak}

Pengaruh angin terhadap pola sebaran tumpahan minyak dilihat dengan citra MODIS mengunakan algoritma NDVI kemudian dideliniasi pada daerah tumpahan minyak. Setelah itu dilakukan overlay terhadap arah sebaran angin pada tiap tanggal tumpahan minyak.
Dari hasil overlay pola arah angin dan sebaran minyak tiap tanggal, dapat dikatakan bahwa minyak cenderung mengikuti pola sebaran angin. Menurut Nontji (2002) bahwa angin merupakan salah satu faktor penting yang dapat membangkitkan gaya arus di permukaan laut. Sehingga berdasarkan hasil yang didapatkan memang benar arah angin mempengaruhi pola sebaran tumpahan minyak di permukaan air.

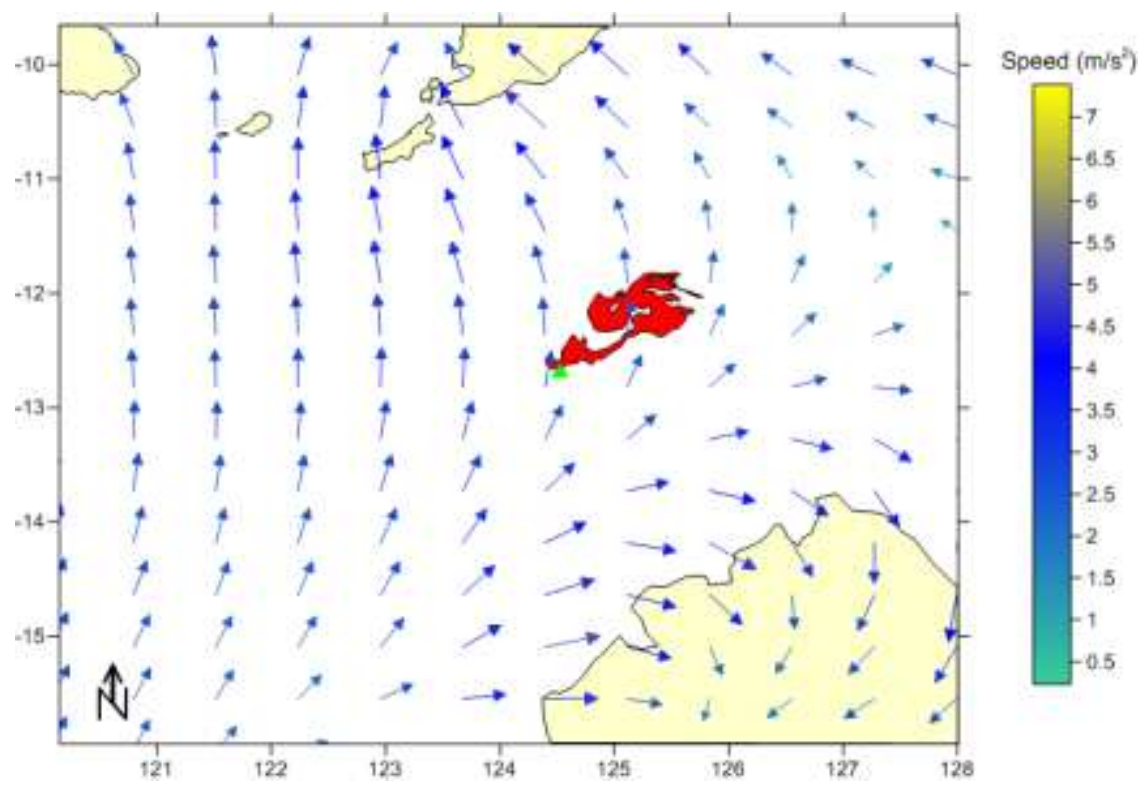

Gambar 11. Pola sebaran angin tanggal 30 Agustus 2009

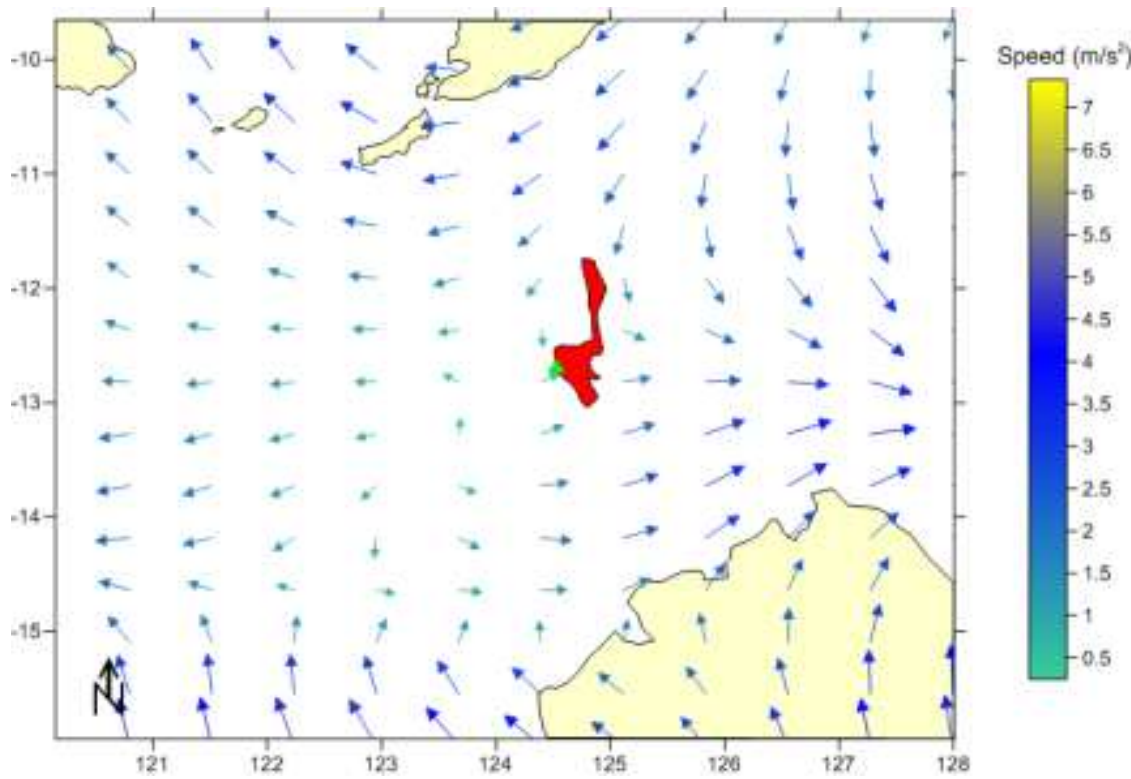

Gambar 12. Pola sebaran angin tanggal 8 September 2009 


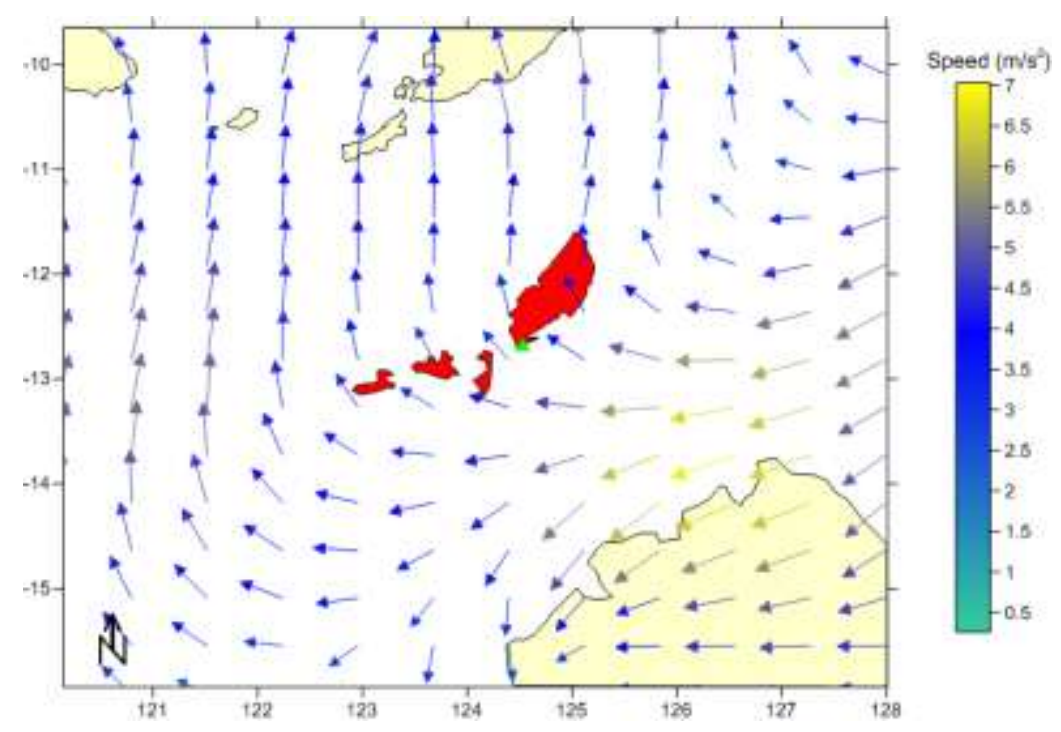

Gambar 13. Pola sebaran angin tanggal 24 September 2009

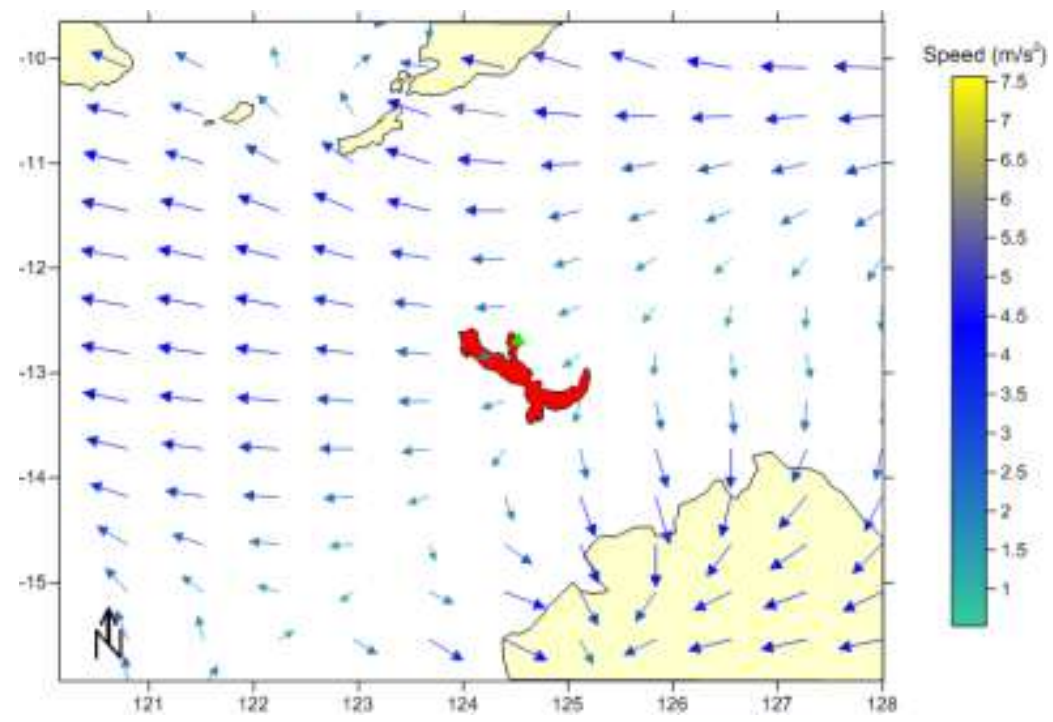

Gambar 14. Pola sebaran angin tanggal 10 Oktober 2009

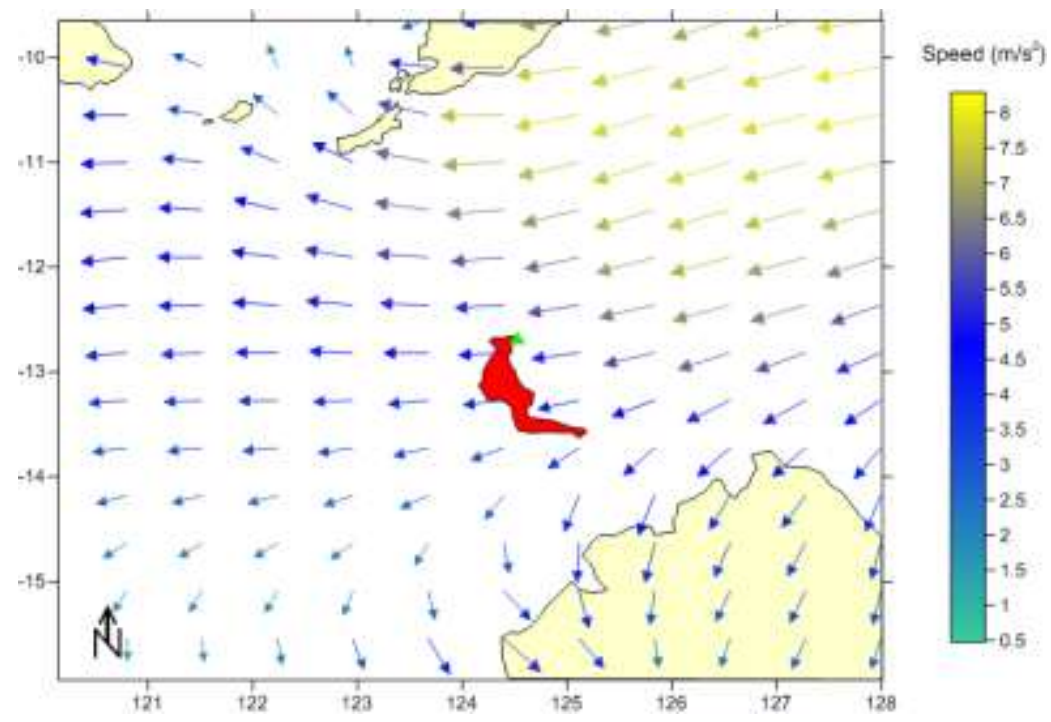

Gambar 15. Pola sebaran angin tanggal 21 Oktober 2009 
Dapat diketahui pula pada Gambar 11 dan 13 bahwa angin cenderung mengarah ke arah utara pada bulan Agustus dan September dengan kecepatan berkisar 2-4 m/ $\mathrm{s}^{2}$. Hal ini berbahaya bagi lingkungan di Indonesia karena jika sewaktu-waktu terjadi tumpahan minyak lagi di daerah tersebut kemungkinan besar akan mengarah ke perairan Indonesia. Berbeda dengan bulan Oktober (Gambar 14 dan 15) arah angin cenderung lebih menuju ke arah selatan yaitu mendekati perairan Australia dengan kecepatan berkisar 3$5.5 \mathrm{~m} / \mathrm{s}^{2}$. Bagaimanapun juga peristiwa tumpahan minyak harus dihindari karena sangat merugikan baik dari segi biologi maupun ekonomi.

\subsection{Pengaruh arus terhadap pola sebaran tumpahan minyak}

Pengaruh arus terhadap pola sebaran tumpahan minyak dilihat dengan citra MODIS mengunakan algoritma NDVI dideliniasi pada daerah tumpahan minyak. Data arus yang didapatkan adalah data rataan tiap lima harian yang kemudian di-overlay terhadap arah sebaran arus pada tiap tanggal tumpahan minyak.

Dilihat dari pola pergerakan arus dan angin tiap tanggal, dapat dikatakan terdapat pola sebaran yang tidak jauh berbeda.Menurut Fingas (2010) faktor utama yang menyebabkan tumpahan minyak di laut menyebar adalah angin dan arus. Berdasarkan hasil overlay pola arah arus dan sebaran minyak bahwa minyak cenderung mengikuti pola sebaran arus laut. Sehingga dapat dikatakan bahwa pergerakan arus dapat mampu mempengaruhi pola sebaran tumpahan minyak dilaut.

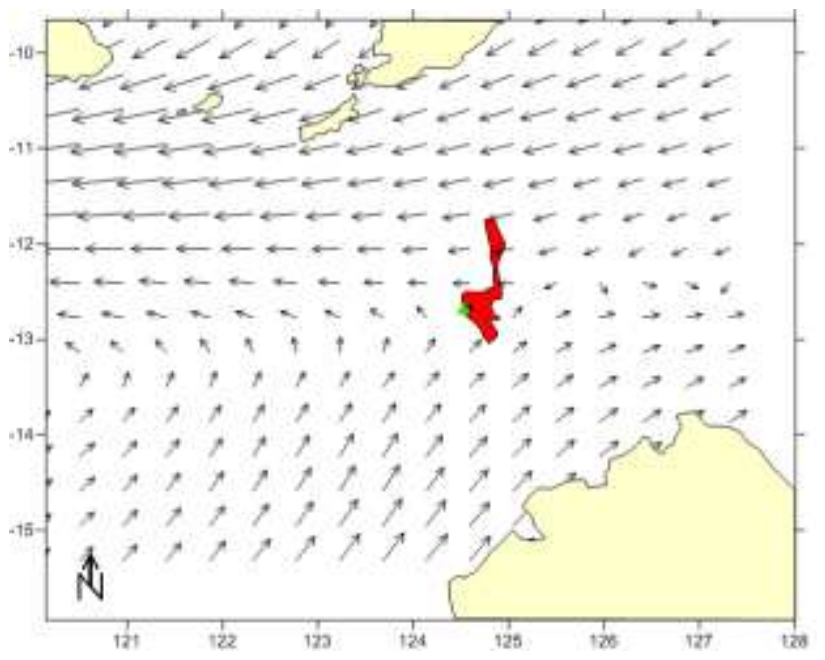

Gambar 16. Pola sebaran arus tanggal 5 - 10 September 2009

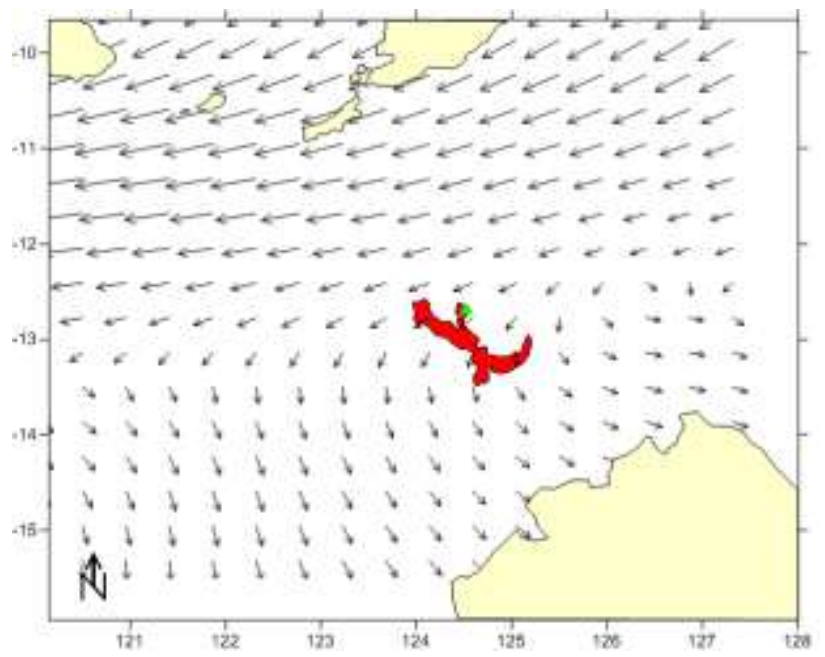

Gambar 17. Pola sebaran arus tanggal 10 - 15 Oktober 2009 




Gambar 18. Pola sebaran arus tanggal 20 - 25 Oktober 2009

Berdasarkan Gambar 16 diketahui bahwa pola arus di daerah tumpahan minyak saling bertemu dari arah utara menuju ke barat dan arus dari arah selatan menuju ke timur yang akan menyebabkan minyak akan tetap di daerah tersebut. Sedangkan gambar 17 dan 18 pergerakan minyak terlihat lebih mengikuti pergerakan pola arus yaitu menuju ke arah selatan.

\section{KESIMPULAN DAN SARAN}

\subsection{Kesimpulan}

Salah satu algoritma yang dapat digunakan untuk citra MODIS dalam mendeteksi tumpahan minyak secara baik adalah algoritma NDVI. Algoritma SST Callison pada citra MODIS tidak dapat digunakan untuk mendeteksi tumpahan minyak namun dapat digunakan untuk mengetahui kisaran suhu pada suatu daerah. Nilai indeks citra MODIS pada daerah tumpahan minyak dengan menggunakan algoritma fluorescence index dan oil spill index akan lebih tinggi dari daerah sekitar yang tidak terkena tumpahan minyak, sedangkan nilai indeks dalam citra MODIS pada derah tumpahan minyak dengan menggunakan algoritma NDVI dan PCA lebih rendah dari daerah yang tidak ada minyak.

\subsection{Saran}

Diperlukan penelitian yang lebih lanjut mengenai pendeteksian tumpa- han minyak di laut dengan citra MODIS mengunakan algoritma baru sehingga menghasilkan visualisasi tumpahan minyak yang lebih jelas lagi.

\section{DAFTAR PUSTAKA}

AES, 2009. Biodiversity Survey of the Montara Field Oil Leak. Australia. AES Applied Ecology Solutions Pty Ltd.

Alesheikh A.A Shahini S. G. 2011. Assesment of Spectral Analysis Methods to Detect and Monitor Oil Spill Using MODIS Data. Iran, SASTECH. 4:4.

Dessì, F., Melisa, Naitzaa L., and A. Marinia. 2008. MODIS data processing for coastal and marine environment monitoring: a study on anomaly detection and evolu-tion In gulf of cagliari (Sardinia-Italy). The International Archives of the Photogrammetry, Remote Sensing and Spatial Information Sciences. (37): 695-698.

Duursma EK dan Marchand M. 1974. Aspects of Organic Marine Pollution in Barnes $\mathrm{H}$ (Ed.), Oceanography and Marine Biology. Allan \& Unwin. London(UK).

Fingas, Mervin F. 2010. Oil Spill Science and Technology. Burlington: USA. Elsevier Inc. 
Krisdiantoro. 2012. Model Sebaran Tumpahan Minyak di Perairan Indramayu, Jawa Barat. Fakultas Perikanan dan Ilmu Kelautan. Skripsi: Tidak Dipublikasikan. Institut Pertanian Bogor. Bogor.

Lillesand, T.M dan F.W.Kiefer.1990. Penginderaan Jauh dan Interpretasi Citra. Diterjemahkan oleh Dulbahri et al. Gadjah mada University Press. Yogyakarta.

Lumban Batu, D.F. 2010. Dampak Tumpahan Minyak Terhadap Ekosistem Perairan. Presentasi Pencemaran Laut Timor. Indonesia Maritim Institut.

Lumban Gaol, J. 2010. Distribusi Spasial Oil Spill Montara di Celah Timor dari Satelit dan Dampaknya Terhadap Sumberdaya Hayati Laut, h. III-9 - III-13. Dalam IPTEK dalam Mitigasi dan Adaptasi Dampak Perubahan Iklim terhadap Ekosistem Pesisir dan Pulau-pulau Kecil. Prosiding Simposium Nasional Pengelolaan Pesisir, Laut dan Pulau-Pulau Kecil. 18 November 2010. Bogor. III. Hal: 9-13.

MODIS.MODIS Technical Specification. http://modis.gsfc.nasa.gov/about/ specifications. php [10 Januari 2013].

Mukhtasor.2007. Pencemaran Pesisir dan Laut. Jakarta. PT. Pradya Paramita.

Nontji. 2002. Laut Nusantara. Penerbit Djambatan. Jakarta.

Paulus, A.C. 2006. Analisis Sebaran Suhu Permukaan Laut dan Kandungan Klorofil-a dengan Menggunakan Data MODIS di Perairan Nusa Tenggara Timur.Fakultas Perikanan dan Ilmu Kelautan. Skripsi: Tidak Dipublikasikan. Institut Pertanian Bogor. Bogor.

Smith, Lindsay. I. 2002. A Tutorial on Principle Component Analysis. [10 Januari 2013].

Walpole, R.E. 1995. Pengantar Statistika. Jakarta: PT. Gramedia Pustaka Utama.

Wicaksono, P. 2008. Perbandingan Kemampuan Citra ASTER dan Landsat 7 ETM+ Dalam Pemetaan Kondisi Kesehatan Terumbu Karang di Pulau Menjangan Besar dan Menjangan Kecil, Kepulauan Karimun Jawa. Bandung. PIT MAPIN XVII: 415-421. 